\title{
Comparative Ecology of \\ Nuclear Waste Ponds and Streams on the Hanford Site
}

Richard M. Emery

M. Colleen McShane

October 1978

Prepared for the U.S. Department of Energy under Contract No. EY-76-C-06-1830

Pacific Northwest Laboratory

Operated for the U.S. Department of Energy by 


\title{
NOTICE
}

This report was prepared as an account of work sponsored by the United States Government. Neither the United States nor the Department of Energy, nor any of their employees, nor any of their contractors, subcontractors, or their employees, makes any warranty, express or implied, or assumes any legal liability or responsibility for the accuracy, completeness or usefulness of any information, apparatus, product or process disclosed, or represents that its use would not infringe privately owned rights.

The views, opinions and conclusions contained in this report are those of the contractor and do not necessarily represent those of the United States Government or the United States Department of Energy.

\author{
PACIFIC NORTHWEST LABORATORY \\ operated by \\ BATTELLE \\ for the \\ UNITED STATES DEPARTMENT OF ENERGY \\ Under Contract EY-76-C-06-1830
}

\author{
Printed in the United States of America \\ Available from \\ National Technical Information Service \\ United States Department of Commerce \\ 5285 Port Royal Road \\ Springfield, Virginia 22151 \\ Price: Printed Copy $\$$; Microfiche $\$ 3.00$
}

$\begin{array}{cc}\text { *Pages } & \begin{array}{c}\text { NTIS } \\ \text { Selling Price }\end{array} \\ 001-025 & \$ 4.50 \\ 026-050 & \$ 5.00 \\ 051-075 & \$ 5.50 \\ 076-100 & \$ 6.00 \\ 101-125 & \$ 6.50 \\ 126-150 & \$ 7.00 \\ 151-175 & \$ 7.75 \\ 176-200 & \$ 8.50 \\ 201-225 & \$ 8.75 \\ 226-250 & \$ 9.00 \\ 251-275 & \$ 10.00 \\ 276-300 & \$ 10.25 \\ & \end{array}$


PNL-2499

33679000561318

\section{Comparative Ecology of Nuclear Waste Ponds and Streams on the Hanford Site}

Richard M. Emery

M. Colleen McShane

October 1978

Prepared for

the U.S. Department of Energy

under Contract No. EY-76-C-06-1830

Pacific Northwest Laboratory

Richland, Washington 99352 


\section{ABSTRACT}

Limnological and radiological parameters were investigated in ponds and streams on the Hanford Site to develop comprehensive radioecological profiles. All but one system receives low-level aqueous rad-wastes from nuclear facilities. The remaining system is a pond formed by the surfacing of groundwater and contains radioactivity as a result of evaporative concentration of naturally occurring nuclides. Attempts were made to determine if amounts of radioactivity present in each aquatic system could be related to ecological variation occurring among them. Maximum dose from the sediments at the water interface and nuclide concentrations in the water are used to differentiate these systems radiologically. While Hanford ponds and streams can be grouped into three catagories of nuclide content, only one system (100- $N$ trench) has dose rates exceeding $1 \mathrm{R} / \mathrm{wk}$. However, maximum $\alpha$ concentrations in Z-19 ditch water and maximum $\beta-\gamma$ concentrations in $100-N$ trench water both exceeded $10^{4} \mathrm{pCi} / \mathrm{l}$.

These aquatic environments support populations of commonly occurring algae, macrophytes, invertebrates, and in some cases, fish. Although the variety in algal populations is reduced in 100-N trench and Z-19 ditch, variety in other types of biota are not apparently associated with amounts of radioactivity. Community structures in these systems appear to be as diverse as those in the Columbia River but less diverse than in some offsite-reference streams. The productivity of plant life, invertebrates and fish in these systems does not appear to be associated with the relative amounts of nuclear waste contamination. Furthermore, their rates of productivity resemble those measured in aquatic environments not associated with nuclear activities. Collectively, these data provide no conclusive evidence that the nuclear wastes discharged into Hanford ponds and streams have affected the colonization, diversity and activity of biota that appear in them.

Based on dose-effects data from the literature, only 100-N trench contains enough radioactivity to be potentially harmful to some aquatic organisms and terrestrial communities. However, this ecosystem does not give clear indication that its biota are influenced by this radiation. The organisms that exist in the radioactive 100-N trench sediments are common to most smaller freshwater environments and also appear in other Hanford aquatic systems. Hence, these nuclear waste ponds and streams cannot be clearly differentiated between offsite systems or among themselves on the basis of a comprehensive ecological profile. 


\section{ACKNOWLEDGMENT}

This study was supported under DOE sponsorship by the Office of Health and Environmental Research. It is intended to provide ecological baseline information for the interpretation of data developed in Rockwe 11 Hanford supported ecological studies at the 200-Area plateau.

For their assistance and advice, we wish to thank the following:

\section{Battelle, Pacific Northwest Laboratories}
R. F. Foster
D. C. Klopfer
M. G. LaRiviere
J. L. Helbling
D. H. McKenzie
T. M. Poston
K. R. Price
R. G. Schreckhise
W. L. Templeton
B. E. Vaughan
D. G. Watson

\section{Rockwell Hanford Operations}

(formerly Atlantic Richfield Hanford Company)

L. E. Bruns

H. L. Maxfield

United Nuclear Inc.

T. E. Dabrowski

M. J. Sula 


\section{CONTENTS}

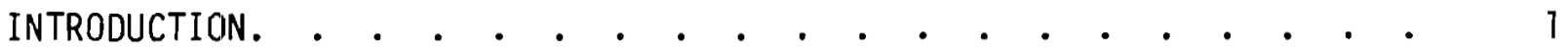

RESULTS • • • • • • • • • • • • • • • • • • • • • • • 2

HISTORICAL AND ECOLOGICAL DESCRIPTIONS OF PONDS AND STREAMS. • • 2

Gable Pond . . . . . . . . . . . . . . . . 2

West Pond. . . . . . . . . . . . . . . . 10

B-Pond. • . . . . . . . . . . . . . . . . 10

B-3 Ditch. . . . . . . . . . . . . . . 10

A-29 Ditch . . . . . . . . . . . . . . . 13

U-Pond. • • • • • • • • • • • • • • • • • 13

Z-19 Ditch . . . . . . . . . . . . . . . . . 13

100-N Trench. • • • • • • • • • • • • • • • . 15

RADIOLOGICAL CHARACTERISTICS OF PONDS AND STREAMS • • • • • • 16

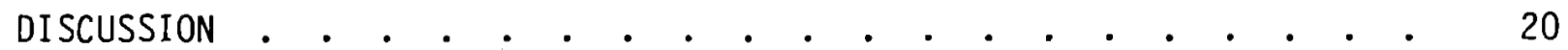

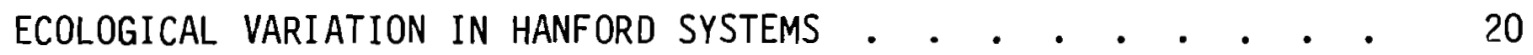

EFFECTS OF IONIZING RADIATION OBSERVED IN OFFSITE

ENVIRONMENTS • • • • • • • • • • • • • • • • • • 25

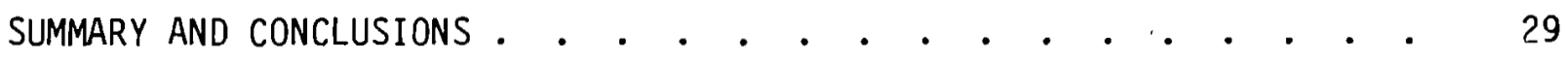

REFERENCES • • • • • • • • • • • • • • • • • • • • 31

APPENDIX A

METHODS AND MATERIALS

Physical Parameters . . . . . . . . . . . . . A-l

Chemical Parameters . . . . . . . . . . . . A-1

Biological Parameters. . . . . . . . . . . . . A-2

Radiological Parameters . . . . . . . . . . . A-4 
APPENDIX B

DETAILED HISTORICAL AN ECOLOGICAL DESCRIPTIONS

OF HANFORD PONDS AND STREAMS

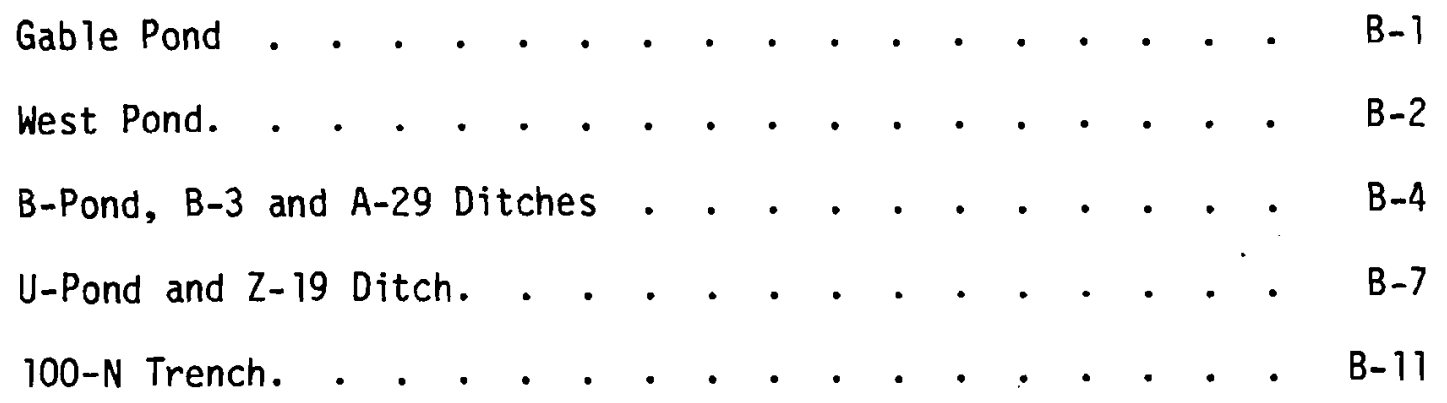




\section{FIGURES}

Figure 1. Map of the Hanford Site showing the location of the study systems. . . . . . . . . . . . . . . . 3

Figure 2. Gable Pond and West Pond showing dimensional information and lists of radionuclides appearing in them. . . . . . . 4

Figure 3. The B-Pond system showing lists of associated radionuclides and dimensional information . $. . \quad . \quad . \quad . \quad . \quad 11$

Figure 4. The U-Pond system showing dimensionl information and list of radionuclides appearing in it . . . . . . . . 14

Figure 5. The 100-N trench shown with dimensional information and lists of radionuclides appearing in it . . . . . . 15

Figure 6. A matrix of maximum nuclide concentrations in water vs. maximum dose rates from sediments, used to suggest a relative grouping of the study sites on the basis of their radiological conditions.

Figure 7. A comparison of doses of ionizing radiation at the sediment-water interface of Hanford aquatic systems with doses observed to cause minor to intermediate damage in aquatic organisms and terrestrial communities . . . . . . 26 


\section{$\underline{\text { TABLES }}$}

Table 1. Physical and chemical characteristics of ponds on the Hanford Site. • . . . . . . . . . . . . . . . 5

Table 2. Appearance of algae in ponds and streams on the Hanford Site. . . . . . . . . . . . . . . 6

Table 3. Quantitative biological characteristics for ponds and streams on the Hanford Site. . . . . . . . . . . . 7

Table 4. Dominant macrophytes observed in ponds and streams on the Hanford Site. . . . . . • . . . . . . . . . 8

Table 5. Appearance of aquatic fauna in ponds and streams on the Hanford Site. • . • . • • • • • . • . • . . . . 9

Table 6. Physical and chemical characteristics for streams (ditches and trenches) on the Hanford Site. . . . . . . . . 12

Table 7. Ranges of radiological characteristics for ponds and streams on the Hanford Site. . . . . . . . . . . 17 


\section{COMPARATIVE ECOLOGY OF NUCLEAR WASTE PONDS AND \\ STREAMS ON THE HANFORD SITE}

\section{INTRODUCTION}

Many aspects of the nuclear industry associated with plutonium processing and reactor operations require a continuous supply of freshwater. Much of this water receives only low-level contamination and can be safely discharged into open ditches and basins at the facility sites. These wastewater discharges create aquatic environments that frequently support diverse ecological communities which adapt to the often unusual thermal, chemical and radiological conditions. Such is the case at Hanford, near Richland, Washington, where several large ponds and streams are maintained to receive waste water from reactor, reprocessing and laboratory operations. These aquatic ecosystems provide a unique opportunity to study ecological profiles occurring in the presence of rad-wastes, with the intent of identifying irregular properties in the biota that might be associated with elevated levels of radioactivity.

The purpose of this work is to provide a comprehensive description of each aquatic system using appropriate physical, chemical, biological and radiological parameters. The overall objective is to determine if these aquatic ecosystems give indications that their radiological conditions affect the biota in terms of occurrence, diversity and productivity. (a)

(a) In the interests of enhancing continuity and efficient comprehension for the reader, we will depart somewhat from traditional scientific journalism. This involves placing the METHODS AND MATERIALS section in APPENDIX $A$ and the detailed site descriptions in APPENDIX $B$, rather than include them in the main body of the text. 


\section{RESULTS}

\section{HISTORICAL AND ECOLOGICAL PROFILES OF PONDS AND STREAMS}

Hanford Operations has created four large ponds on the 200-Area plateau. These are U-Pond in the 200-West Area, B-Pond lying east of the 200-East Area, and Gable and West Ponds in the 200-North Area (Figure 1). Three of the study streams are associated with two of these ponds. A-29 and B-3 ditches carry water to B-Pond and Z-19 ditch discharges into U-Pond. A fourth stream, 100-N trench, lies immediately northeast of the $\mathrm{N}$-reactor site near the Columbia River (Figure 1).

A11 of these aquatic systems have appeared in the Hanford area since the beginning of the Manhattan Project in 1943. The water supply for these systems, except West Pond and 100-N trench, is withdrawn from the Columbia River near the $B$ and $D$ reactor sites (Figure 1). This supply serves the processing and waste handling facilities in the 200 Areas and is used mainly as cooling water. After passing through these facilities, it is discharged into pipes and ditches leading to the ponds. All ponds except West Pond receive these facilities' effluents. West Pond is a window in the ground water table and is fed from underground sources. It appeared in the 200-North Area when large quantities of river water began reaching the 200 Areas. River water is withdrawn directly from the $\mathrm{N}$-reactor site (Figure 1) to supply its operations and some of the effluents are discharged into 100-N trench.

Since the ecological assessment of Hanford aquatic systems has involved a large number of study sites along with numerous data for each site, we will provide here only an overview of the major distinguishing characteristics. This will involve summarizing the pertinent properties of each system that are essential for descriptive and comparative purposes. The reader may refer to Appendix $B$ to find more detailed descriptions from which the se simplified profiles were developed.

\section{Gable Pond}

This pond was created in the 200 North Area in 1957 to receive cooling water from the Purex Plant where reactor fuels are processed (Figures 1 and 2). It contains low-level quantities of actinides and mixed fission 


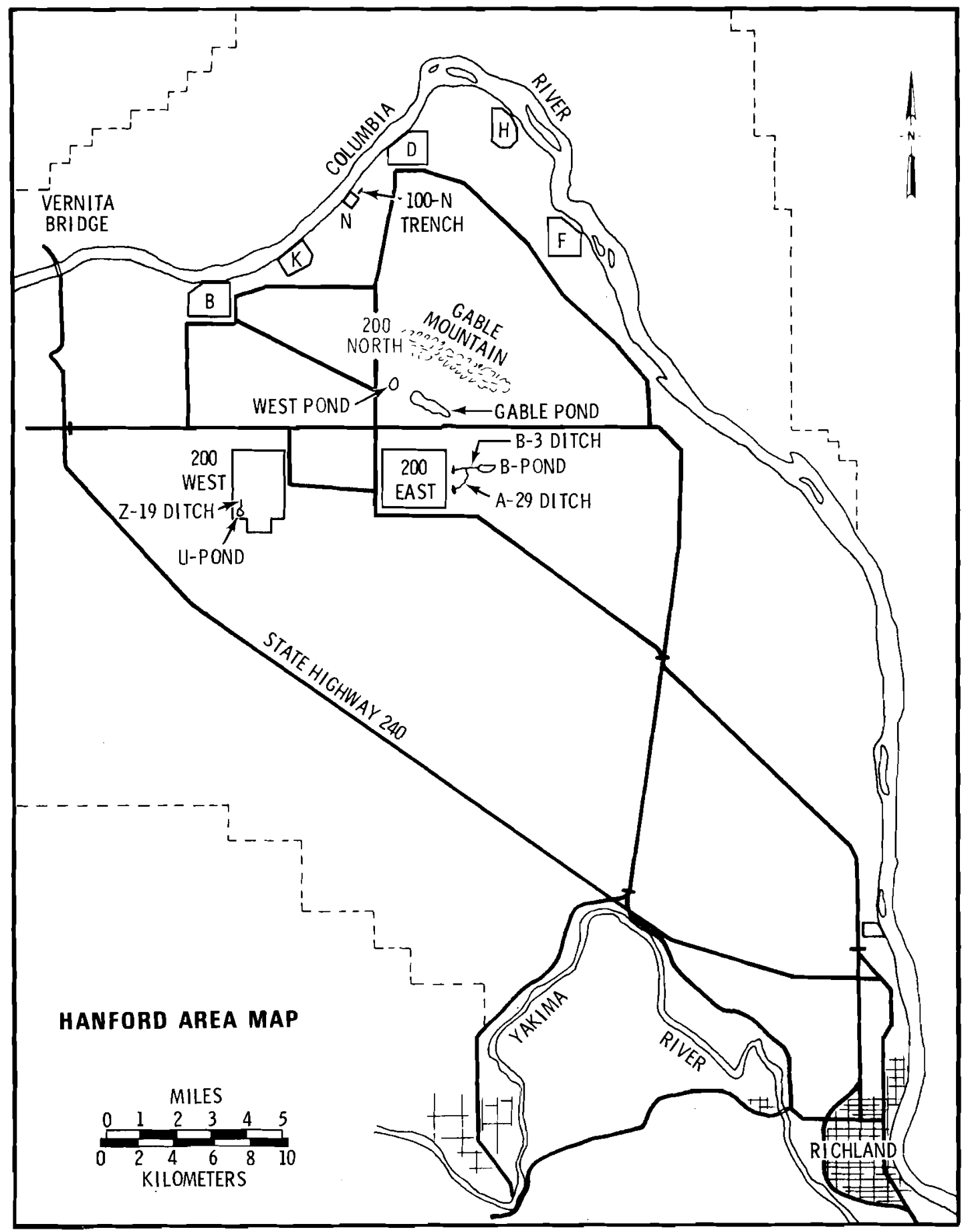

FIGURE 1. Map of the Hanford Site showing the location of the study systems. Reactor sites are located along the Columbia River and are designated by letter. Only the $\mathrm{N}$-reactor is currently in operation. 


\section{GABLE POND}

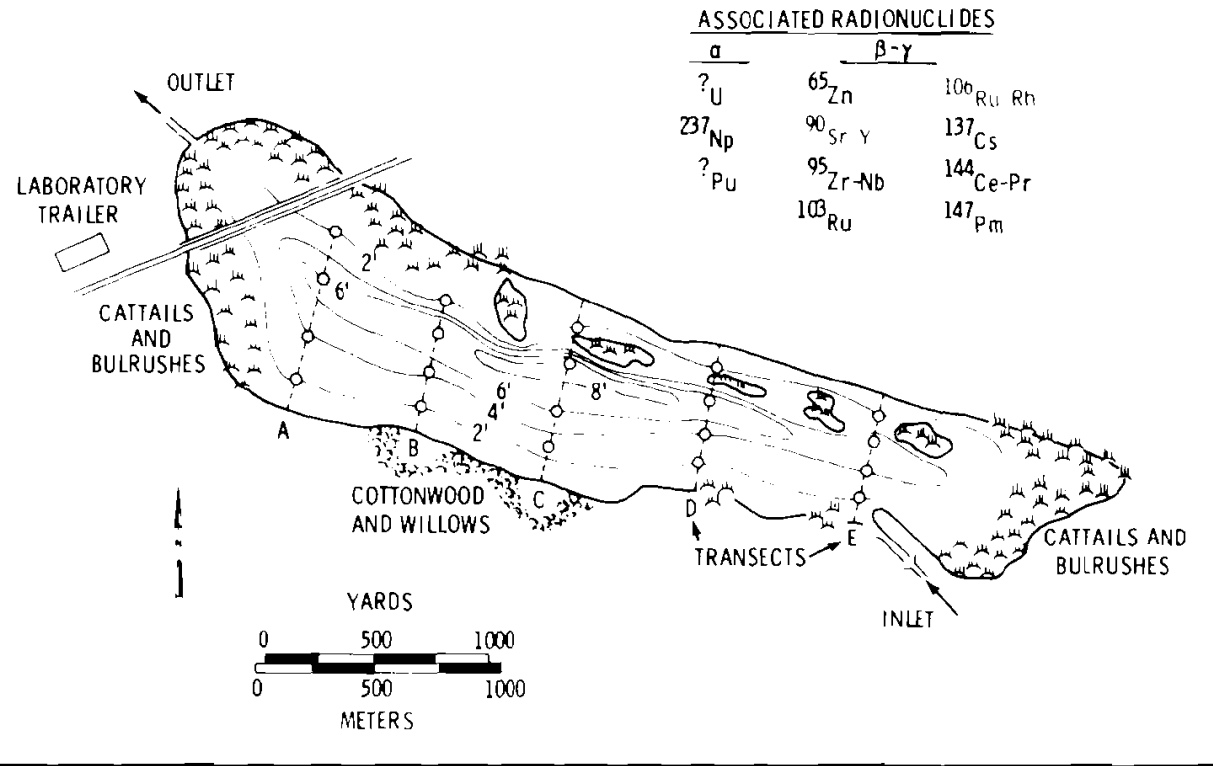

\section{WEST POND}

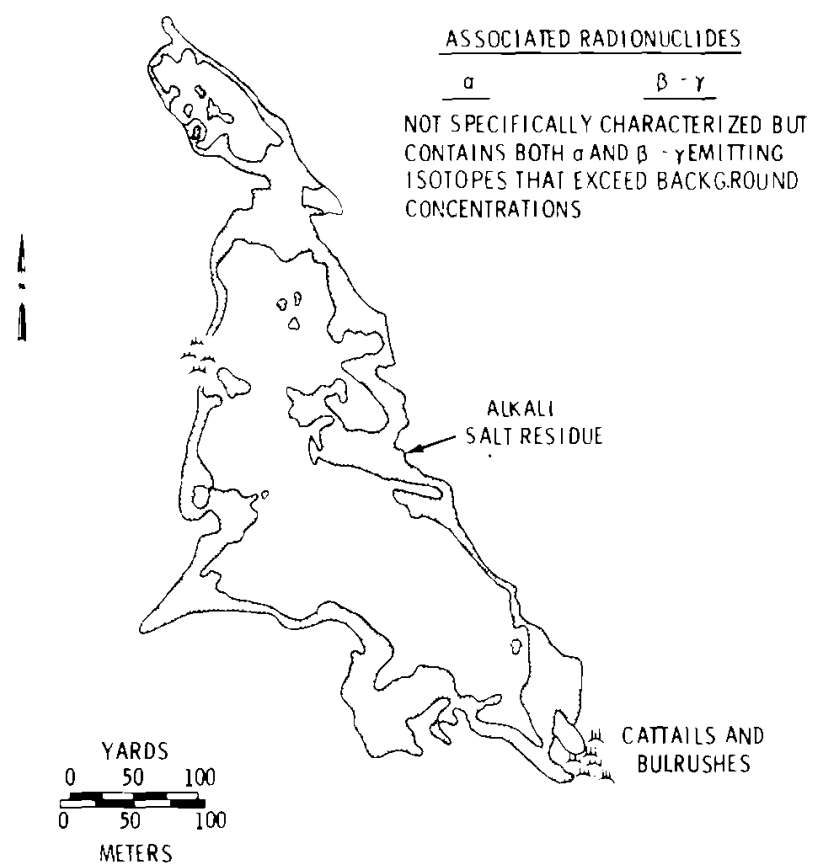

FIGURE 2. Gable Pond and West Pond showing dimensional information and lists of radionuclides appearing in them. 
products (Figure 2). It is the largest of the Hanford ponds and has a relatively slow flushing rate (Table 1). Seston concentrations are relatively low and sedimentation rates are moderate (Table 1). The algal population is mainly periphytic and shows moderate colonization pressure (Tables 2 and 3 ). This pond supports the most prolific populations of submerged and emergent macrophytes at Hanford (Table 4). Invertebrates are relatively diverse and abundant, and this population shows the highest colonization pressure of all study ponds (Tables 3 and 5). Goldfish also live in Gable Pond.

TABLE 1. Physical and chemical characteristics of ponds on the Hanford Site. Means are shown with 95\% confidence values (i.e., mean + confidence value $=95 \%$ confidence interval about the mean).

\begin{tabular}{|c|c|c|c|c|}
\hline $\begin{aligned} \text { Surface area } & \left(\mathrm{m}^{2}\right) \\
& {[\text { acres }] }\end{aligned}$ & $\begin{array}{c}\frac{\text { Gable Pond }}{287,300} \\
{[71.0]}\end{array}$ & 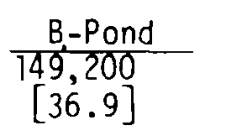 & $\begin{array}{c}\frac{U-P o n d}{56,700} \\
{[14.0]}\end{array}$ & $\frac{\text { West Pond }}{77,800}$ \\
\hline $\begin{aligned} \text { Volume } & \left(\mathrm{m}^{3}\right) \\
& {[\mathrm{acre}-\mathrm{ft}] }\end{aligned}$ & $\begin{array}{l}431,000 \\
{[350]}\end{array}$ & $\begin{array}{l}233,200 \\
{[190]}\end{array}$ & $\begin{array}{l}22,700 \\
{[18.4]}\end{array}$ & $\begin{array}{l}31,100 \\
{[25.1]}\end{array}$ \\
\hline $\begin{aligned} \text { Mean depth } & (\mathrm{m}) \\
& {[\mathrm{ft}] }\end{aligned}$ & $\begin{array}{c}1.5 \\
{[4.9]}\end{array}$ & {$\left[\begin{array}{l}1.6 \\
{[5.2]}\end{array}\right.$} & {$\left[\begin{array}{l}0.4 \\
{[1.3]}\end{array}\right.$} & {$\left[\begin{array}{l}0.4 \\
1.3\end{array}\right]$} \\
\hline Retention Time (hrs) & $504 \pm 211$ & $424 \pm 183$ & $37 \pm 4$ & $-(a)$ \\
\hline Temperature Range $\left({ }^{\circ} \mathrm{C}\right)$ & $0-25.3$ & $0-25.0$ & $0-28.4$ & $0-25.5$ \\
\hline Insolation Range (Langley's) & $20-253$ & $20-253$ & $20-253$ & $20-253$ \\
\hline Seston $(m g / l)$ & $14.5+10.9$ & $12.2+17.4$ & $24.0 \pm 8.9$ & $21.6 \pm 9.6$ \\
\hline $\begin{array}{l}\text { Sedimentation Rate } \\
\left(\mathrm{mg} / \mathrm{cm}^{2} \text { per day }\right)\end{array}$ & $2.43 \pm 0.76$ & $0.81 \pm 0.51$ & $2.24 \pm 1.42$ & $11.20 \pm 6.50$ \\
\hline $\mathrm{pH}$ Range & $7.8-8.7$ & $7.0-9.0$ & $7.0-9.5$ & $9.7-10.0$ \\
\hline Alkalinity (mg/e as $\left.\mathrm{CaCO}_{3}\right)$ & $58.4 \pm 6.1$ & $57.1 \pm 4.8$ & $95.2 \pm 6.5$ & $9009 \pm 1924$ \\
\hline Diss. $\mathrm{O}_{2}$ Range $(\mathrm{mg} / \mathrm{l})$ & $7.9-12.7$ & $8.1-13.8$ & $9.0-13.00$ & $8.0-13.8$ \\
\hline Hardness ( $\mathrm{mg} / \mathrm{l}$ as $\mathrm{CaCO}_{3}$ ) & $67.4 \pm 6.0$ & $68.0 \pm 4.2$ & $72.4 \pm 14.1$ & $121.8 \pm 7.6$ \\
\hline $\begin{array}{l}\text { Conduct ivity } \\
\quad\left(\mu \mathrm{mhos} / \mathrm{cm} 025^{\circ} \mathrm{C}\right)\end{array}$ & $1327 \pm 104$ & $1251 \pm 170$ & $1553 \pm 132$ & $229,698 \pm 42,292$ \\
\hline Total $\mathrm{NO}_{3}-\mathrm{NO}_{2}-\mathrm{N}(\mathrm{mg} / \mathrm{l})$ & $0.18 \pm 0.07$ & $3.65 \pm 1.33$ & $0.28 \pm 0.08$ & - \\
\hline Total $\mathrm{NH}_{3}-\mathrm{N}(\mathrm{mg} / \ell)$ & $0.38 \pm 0.10$ & $1.04 \pm 0.51$ & $0.45 \pm 0.20$ & $2.61 \pm 0.40$ \\
\hline Ortho $\mathrm{PO}_{4}-\mathrm{P}(\mu \mathrm{g} / \ell)$ & $1.0 \pm 0.1$ & $4.5 \pm 4.2$ & $57.8 \pm 25.1$ & $2050 \pm 180$ \\
\hline Total $\mathrm{PO}_{4}-\mathrm{P}(\mu \mathrm{g} / \ell)$ & $38.0 \pm 10.0$ & $40.4 \pm 10.0$ & $123.0 \pm 56.0$ & $2160 \pm 140$ \\
\hline Total $\mathrm{SiO}_{2}-\mathrm{Si}(\mathrm{mg} / \ell)$ & $0.99 \pm 0.22$ & $1.53 \pm 0.41$ & $0.80 \pm 0.43$ & $0.23 \pm 0.21$ \\
\hline
\end{tabular}

(a) No data available 
TABLE 2. Appearance of algae in ponds and streams on the Hanford Site. The presence of a taxon is indicated by a "+", notably large abundance by a "++", and no symbol indicates an absence.

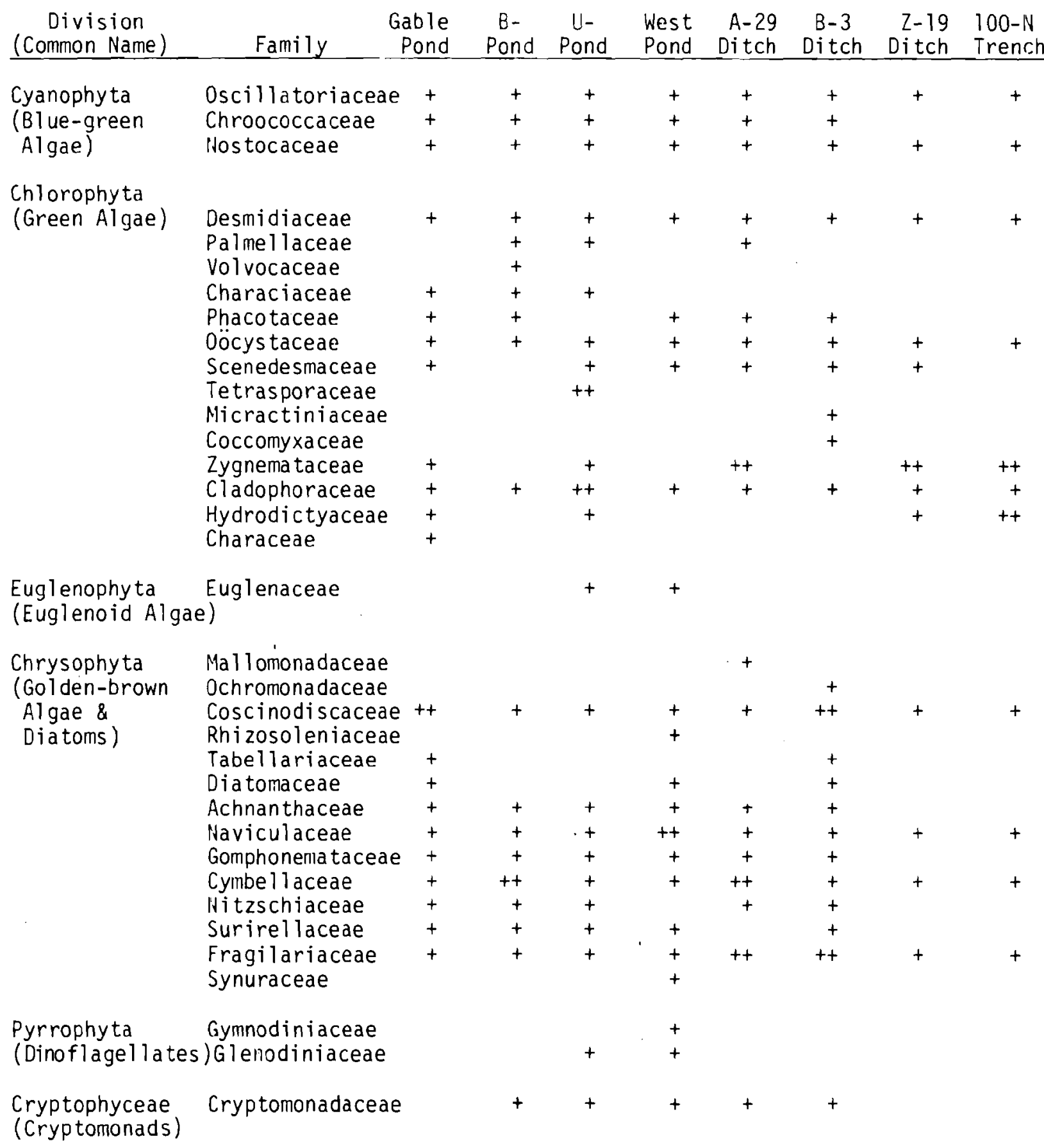




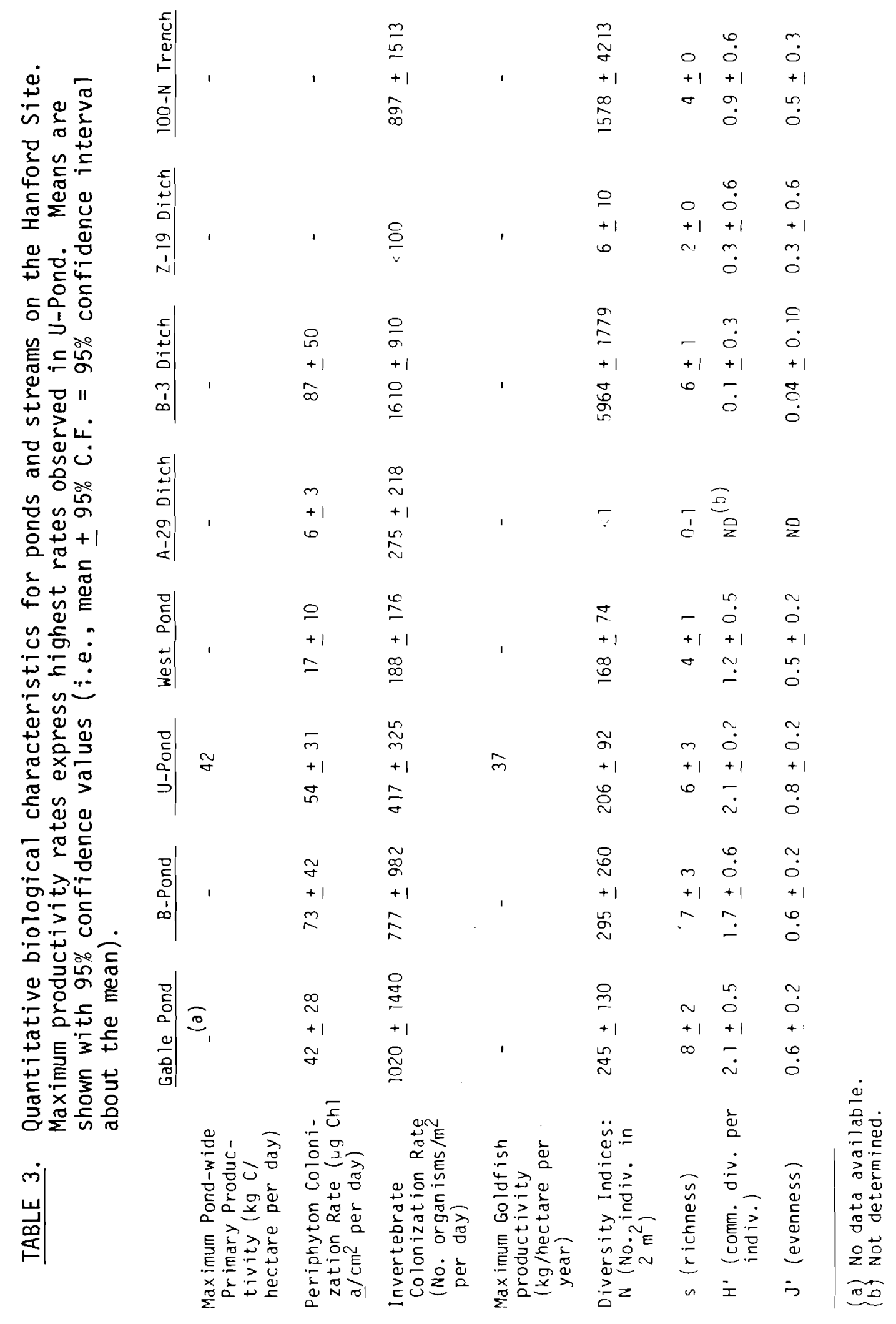


TABLE 4. Dominant macrophytes observed in ponds and streams on the Hanford Site. The presence of a taxon is indicated by a "+", notably large abundance by a "++", and no symbol indicates an absence.

\begin{tabular}{|c|c|c|c|c|c|c|c|c|c|}
\hline Common Name & Genus & $\begin{array}{r}\text { Gable } \\
\text { Pond }\end{array}$ & $\begin{array}{c}\text { B- } \\
\text { Pond }\end{array}$ & $\begin{array}{c}\text { U- } \\
\text { Pond }\end{array}$ & $\begin{array}{l}\text { West } \\
\text { Pond } \\
\end{array}$ & $\begin{array}{r}A-29 \\
\text { Ditch } \\
\end{array}$ & $\begin{array}{c}\text { B-3 } \\
\text { Ditch }\end{array}$ & $\begin{array}{r}Z-19 \\
\text { oitch }\end{array}$ & $\begin{array}{l}100-11 \\
\text { Trench }\end{array}$ \\
\hline Horsetail & Equisetum & + & & + & & & & & \\
\hline Pondweed & Potamogeton & ++ & + & ++ & & & & ++ & \\
\hline Hornwort & Ceratophy 1 lum & ++ & & & & & & & \\
\hline Water Milfoil & Myriophyl lum & ++ & & & & & & & \\
\hline Duckweed & Lemna & & & + & & & & & \\
\hline Cattail & Typha & + & + & ++ & + & + & + & ++ & \\
\hline Bulrush & Scirpus & + & + & + & + & + & ++ & + & + \\
\hline Silartweed & Polygonum & & & + & & & & & \\
\hline Speedwell & Veronica & & & & & + & + & + & + \\
\hline Watercress & Rorippa & & & + & & & & + & \\
\hline wild Lettuce & Lactuca & & & + & & & & + & \\
\hline Willow & Salix & + & & + & & & & & \\
\hline Cottonwood & Populus & + & & + & & + & & + & \\
\hline
\end{tabular}


TABLE 5. Appearance of aquatic fauna in ponds and streams on the Hanford Site. Presence of a taxon is indicated by a "+", notably large abundance of a taxon by a "++", and no symbol indicates an absence.

\begin{tabular}{|c|c|c|c|c|c|c|c|c|c|}
\hline Common & Taxon & $\begin{array}{r}\text { Gable } \\
\text { Pond }\end{array}$ & $\begin{array}{l}\text { B- } \\
\text { Pond }\end{array}$ & $\begin{array}{l}\text { U- } \\
\text { Pond }\end{array}$ & $\begin{array}{l}\text { West } \\
\text { Pond } \\
\end{array}$ & $\begin{array}{r}\text { A-29 } \\
\text { Ditch } \\
\end{array}$ & $\begin{array}{c}\text { B-3 } \\
\text { Ditch }\end{array}$ & $\begin{array}{r}Z-19 \\
\text { Ditch }\end{array}$ & $\begin{array}{l}\text { 100-N } \\
\text { Trench } \\
\end{array}$ \\
\hline Fla tworm & Dugesia & + & + & + & & + & + & & \\
\hline Leech & Hirundinea & & + & + & & & & & \\
\hline Segmented worm & 01 igochaeta & + & + & + & $+t$ & + & + & + & + \\
\hline Waterflea & Daphnia & t+ & + & t+ & & & & & \\
\hline Seed Shrimp & $\overline{\text { Ostracoda }}$ & & & + & & & & & \\
\hline Scud & Hyalella & ++ & ++ & + & & & + & & \\
\hline Wa termi te & Hydrocarina & & & + & & & & & \\
\hline Mayfly & Baetidae & + & + & + & & & & & \\
\hline Dragonfly & Aeschna & t+ & + & ++ & & & + & & + \\
\hline Dragon & LibelTula & + & + & ++ & & & & & \\
\hline Dragonfly & Tramea & & & + & & & & & \\
\hline Dragonfly & Erythemis & & & + & & & & & \\
\hline Dragonfly & $\overline{A n a x}$ & + & + & & & & & & \\
\hline Damselfly & Ischnura & + & + & $+t$ & + & & + & + & + \\
\hline Waterstrider & Gerridae & + & + & + & & + & + & + & \\
\hline Backswimner & Notonectidae & + & + & ++ & + & & & + & + \\
\hline $\begin{array}{l}\text { Creeping } \\
\text { Water Bug }\end{array}$ & Naucoridae & & & + & & & & & \\
\hline Water Scorpion & Nepidae & + & & + & & & & & \\
\hline Giant Water Bus & Belostomatidae & + & & + & & & & & \\
\hline Water Boatman & Corixidae & + & $+t$ & ++ & + & & & + & \\
\hline Caddisfly & Tricoptera & + & + & + & + & & + & & \\
\hline $\begin{array}{l}\text { Predaceous } \\
\text { Diving Beetle }\end{array}$ & Dytiscidae & + & + & + & & & + & + & \\
\hline $\begin{array}{l}\text { Water Scavenger } \\
\text { Beetle }\end{array}$ & Hydrophilidae & + & + & & & & & & \\
\hline $\begin{array}{l}\text { Crawling } \\
\text { Water Beetle }\end{array}$ & Halipidae & + & & & & & & & \\
\hline Beetle & Amphizoidae & & & + & & & & & \\
\hline Beetle & Noteridae & & & + & & & & & \\
\hline Beetle & Helodidae & & & + & & & & & \\
\hline Midge & Chironomidae & + & + & + & + & t+ & ++ & + & t+ \\
\hline Black Fly & Simuliidae & & & & & + & & & \\
\hline Shore Fly & Ephydridae & & & & + & & & & \\
\hline $\begin{array}{l}\text { Aquatic } \\
\text { Caterpiller }\end{array}$ & Nymphul idae & & + & & & & + & & \\
\hline Snail & Physa & + & + & + & & & & & \\
\hline Snail & Lymnaea & ++ & & ++ & & & & & ++ \\
\hline Snail & Planorbidae & + & + & & & & & & \\
\hline Goldfish & Carassius & + & + & ++ & & & + & & \\
\hline
\end{tabular}




\section{West Pond}

In 1957, this ground water window appeared in a depression in the 200 North Area (Figures 1 and 2 ). This relatively small pond retains its water long enough to permit considerably evaporative concentration of soluble salts, which has elevated its ionic concentrations (Table 1). This pond has not been used as a nuclear waste facility, but does have detectable levels of some radionuclides. It has relatively high seston concentrations in addition to the highest sedimentation rates among ponds (Table 1). The variety of algae is relatively broad, but the colonization pressure of this population was the lowest among ponds (Tables 2 and 3 ). It supports limited macrophyte and invertebrate populations. Indicators of the invertebrate's variety, diversity, and colonization pressure were the lowest among Hanford ponds (Tables 3 and 5). No fish life appears in this pond.

\section{B-Pond}

This pond was created in 1945 to receive cooling water from the 200-East Area encapsulation facility via B-3 ditch (Figures 1 and 3 ). It also receives cooling water and occasional chemical wastes from an acid fractionator via A-29 ditch. It contains small amounts of actinides and mixed fission products (Figure 3 ). It flushes at a moderate rate, and its seston concentrations and sedimentation rates are lowest among Hanford ponds (Table 1). While most water chemistry parameters are similar to those of regional aquatic environments, nitrogen concentrations are substantially higher (Table 1). The algal population is mainly periphytic and shows the highest colonization pressure among ponds (Tables 2 and 3 ). The macrophytic population is sparse (Table 4). The invertebrate population shows moderate variety, diversity, and colonization pressure (Table 2 and 5), and there is a small population of goldfish.

\section{B-3 Ditch}

This ditch was created in 1945 and partially rerouted in 1973. It transports the main water supply to B-Pond (Figure 3 and Table 4 ). It carries only cooling water and contains a small amount of mixed fission products. It has a slightly elevated temperature range and higher nitrogen concentrations than most regional aquatic environments (Table 6). This ditch supports a relatively large variety of algae, most of which are periphytic and colonize more rapidly than those of other Hanford study sites (Tables 2 and 3 ). The variety of macrophytes is small, but there are some dense stands of emergent vegetation (Table 6). The variety of invertebrate life appears to be relatively small, but greatest among Hanford streams (Table 5). Although the colonization pressure of the invertebrate population is higher than at other study sites; the diversity is quite low (Table 3 ). There is also a small goldfish population. 


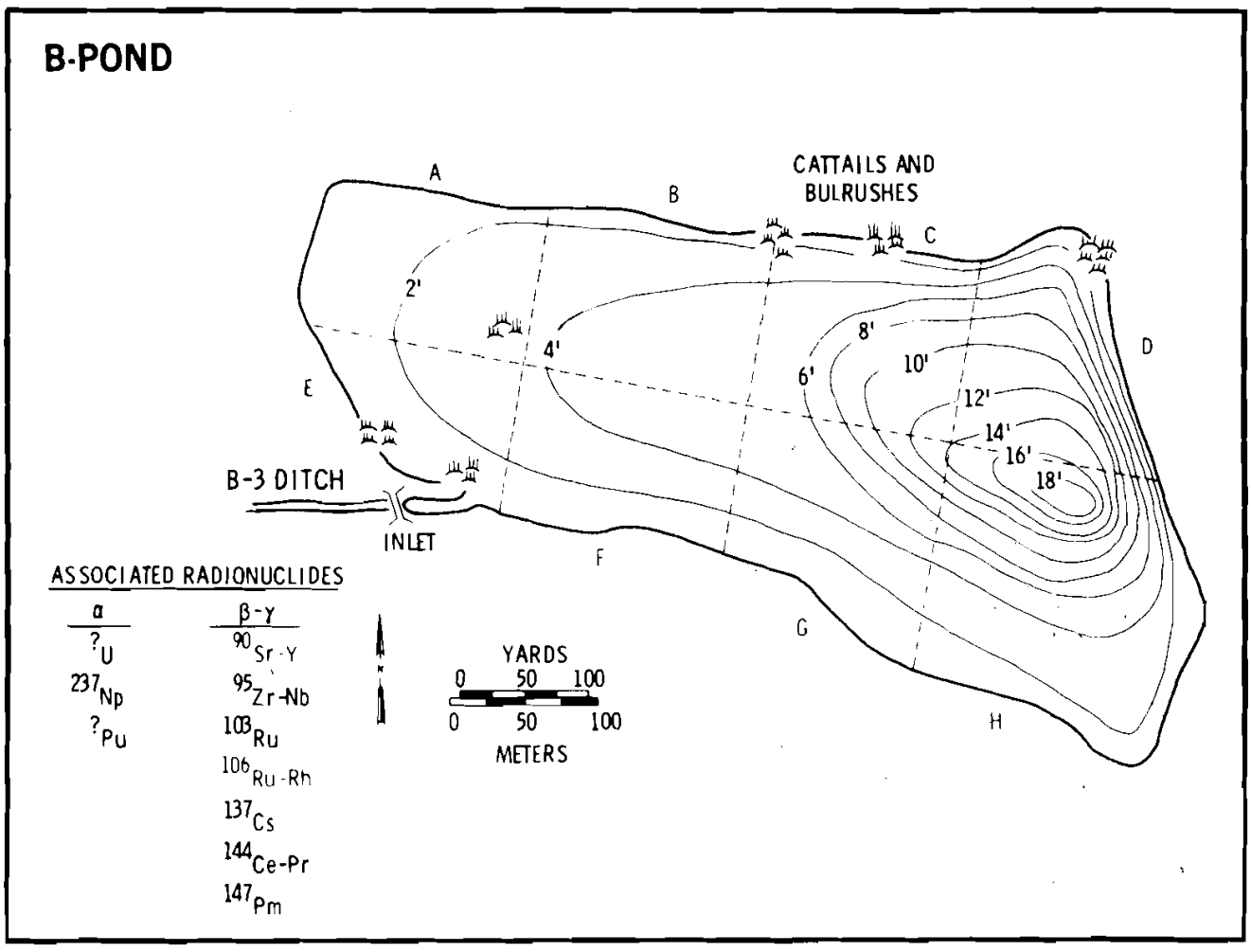

\section{B-3 AND A-29 DITCHES}

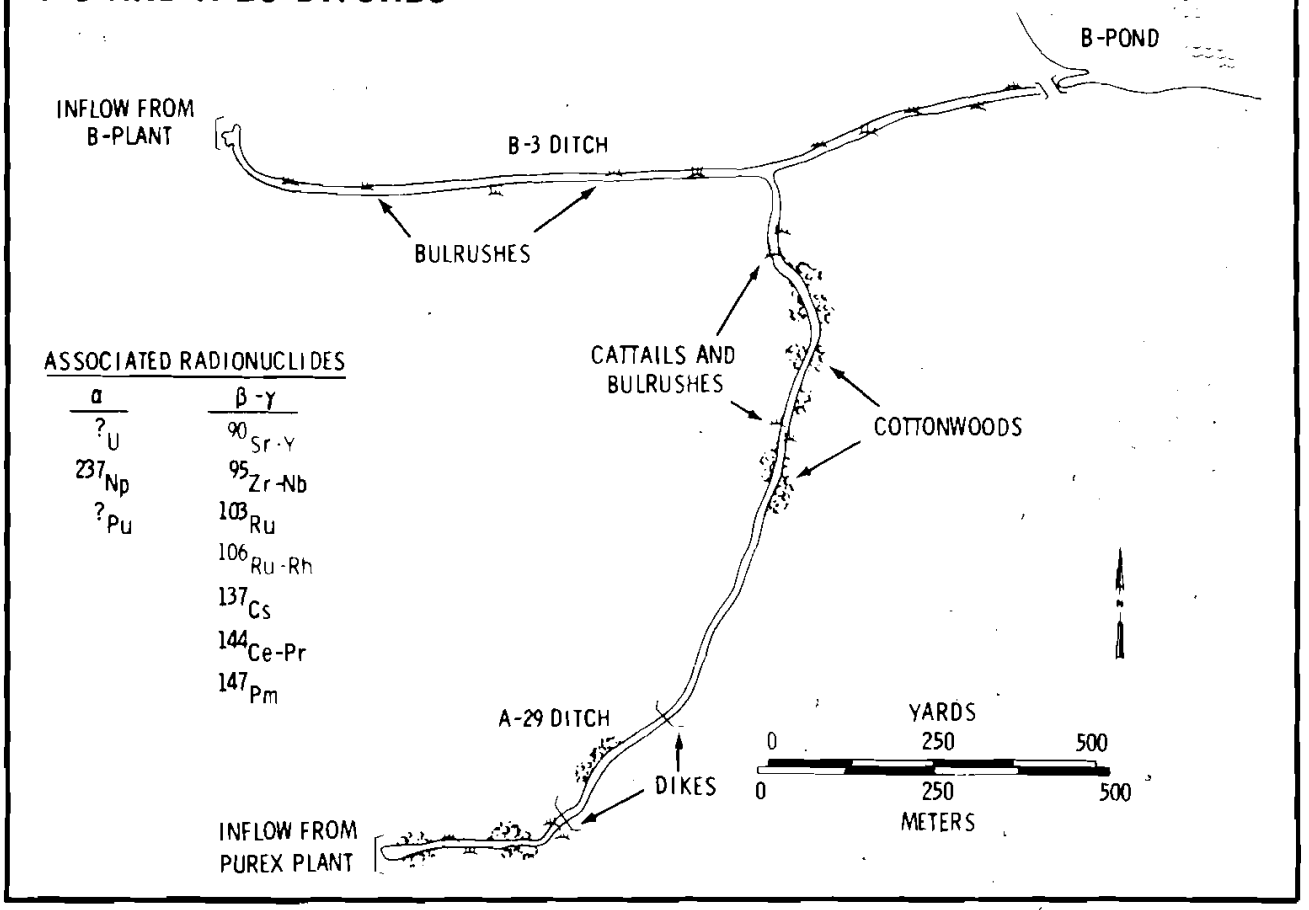

FIGURE 3. The B-Pond system showing lists of associated radionuclides and dimensional information. 
TABLE 6. Physical and chemical characteristics for streams (ditches and trenches) on the Hanford Site. Means are shown with $95 \%$ confidence values (i.e., mean + confidence value $=95 \%$ confidence interval ábout the mean).

\begin{tabular}{|c|c|c|c|c|}
\hline & A-29 Ditch & B-3 Ditch & Z-19 Ditch & 100-N Trench \\
\hline Length $(\mathrm{m})$ & $\begin{array}{c}1325 \\
{[4350]}\end{array}$ & $\begin{array}{c}1200 \\
{[3940]}\end{array}$ & $\begin{array}{c}885 \\
{[2900]}\end{array}$ & $\begin{array}{c}423 \\
{[1380]}\end{array}$ \\
\hline $\begin{array}{r}\text { Maximum depth }(\mathrm{m}) \\
{[\mathrm{ft}]}\end{array}$ & $\begin{array}{l}<0.5 \\
{[<2]}\end{array}$ & {$\left[\begin{array}{r}<1 \\
{[3]}\end{array}\right.$} & {$\left[\begin{array}{l}0.5 \\
{[<2]}\end{array}\right.$} & {$\left[\begin{array}{l}<1 \\
{[<3}\end{array}\right]$} \\
\hline Flow Rate $\left(\mathrm{m}^{3} / \mathrm{min}\right)$ & $\begin{array}{l}1.53 \pm 0.40 \\
{[0.9 \pm 0.2]}\end{array}$ & $\begin{array}{l}10.77 \pm 4.45 \\
{[6.3 \pm 2.6]}\end{array}$ & $\begin{array}{l}0.65 \pm 0.08 \\
{[0.4 \pm 0.05]}\end{array}$ & $\begin{array}{l}\simeq 06.6 \\
{[\simeq 3.9]}\end{array}$ \\
\hline Temperature Range $\left({ }^{\circ} \mathrm{C}\right)$ & $10.5-24.6$ & $13.4-27.0$ & $10.0-25.5$ & $18.0-37.0$ \\
\hline $\begin{array}{l}\text { Insolation Range } \\
\text { (Langley's) }\end{array}$ & $20-253$ & $20-253$ & $20-253$ & $20-253$ \\
\hline Seston $(\mathrm{mg} / \mathrm{l})$ & $1.94 \pm 1.26$ & $2.23 \pm 1.63$ & $13.25 \pm 5.07$ & $(c)$ \\
\hline pH Range & $6.5-7.6^{(b)}$ & $7.4-8.1$ & $6.9-8.0$ & $7.5-8.0$ \\
\hline $\begin{array}{l}\text { Alkalinity } \\
\left(\mathrm{mg} / \mathrm{l} \text { as } \mathrm{CaCO}_{3}\right)\end{array}$ & $53.6 \pm 4.5$ & $55.2 \pm 4.6$ & $73.2 \pm 4.9$ & $39.7 \pm 6.8$ \\
\hline Diss. $0_{2}$ Range $(\mathrm{mg} / \mathrm{l})$ & $7.8-11.2$ & $7.8-10.5$ & $8.0-12.1$ & $=8.0$ \\
\hline Hardness $\left(\mathrm{mg} / \mathrm{l}\right.$ as $\left.\mathrm{CaCO}_{3}\right)$ & $63.8 \pm 3.0$ & $68.2+3.7$ & - & $49.7 \pm 7.0$ \\
\hline $\begin{array}{l}\text { Conduct ivity } \\
\left(\mu \mathrm{mhos} / \mathrm{cm} \text { (22 } 25^{\circ} \mathrm{C}\right)\end{array}$ & $1260 \pm 63$ & $1433 \pm 140$ & - & $110 \pm 21$ \\
\hline Total $\mathrm{NO}_{3}-\mathrm{NO}_{2}-\mathrm{N}(\mathrm{mg} / \mathrm{l})$ & $0.19 \pm 0.15$ & $3.74 \pm 1.28$ & $0.30 \pm 0.36$ & - \\
\hline Total $\mathrm{NH}_{3}-\mathrm{N}(\mathrm{mg} / \mathrm{l})$ & $0.67 \pm 0.84$ & $1.61 \pm 1.10$ & $0.09 \pm 0.04$ & - \\
\hline Ortho $\mathrm{PH}_{4}-\mathrm{P}(\mu \mathrm{g} / \ell)$ & $11.9 \pm 10.2$ & $9.8 \pm 7.6$ & $90.0 \pm 49.7$ & - \\
\hline Total $1 \mathrm{PO}_{4}-\mathrm{P}(\mu \mathrm{g} / \mathrm{l})$ & $45.1 \pm 9.0$ & $48.2 \pm 10.8$ & $105.0 \pm 54.0$ & - \\
\hline Total $\mathrm{SiO}_{2}-\mathrm{Si}(\mathrm{mg} / \mathrm{l})$ & $2.08 \pm 0.42$ & $2.01 \div \pm 0.42$ & $4.73 \pm 8.35$ & - \\
\hline
\end{tabular}

(a) Discharges into Z-19 ditch were substantially reduced in March 1976.

(b) Range may be broader on an intermittent basis.

(c) No data available. 


\section{$\underline{\text { A-29 Ditch }}$}

This ditch carries chemical sewer wastes and cooling water into B-Pond (Figure 3). It was formed in 1955 to receive Purex laboratory wastes, but since 1972 only carries cooling water from an acid fractionator along with occasional pulses of waste chemicals including oils and strong caustics and corrosives. Despite these discharges, routine water sampling did not reveal unusual chemical conditions (Table 6 ). It contains very small quantities of mixed fission products (Figure 3 ). The algal population is mainly periphytic, showing moderate variety, but the colonization pressure is lowest among the Hanford study sites (Tables 2 and 3 ). It supports several stands of emergent macrophytes (Table 4). The variety, diversity, and colonization pressure of the invertebrates are quite low (Tables 3 and 5), and there is no fish life present.

\section{$\underline{\text { U-Pond }}$}

This pond was formed in 1944 to receive low-level wastes from plutonium processing and reclamation facilities, a uranium recovery plant, and other supportive laboratories in the 200-West Area via a series of Z-ditches (Figures 1 and 4). Z-19 ditch presently carries wastes from these facilities, which have reduced their operations in recent years (Figure 4 ). Since 1974, the pond's major supply of water has come from an evaporator-crystallizer plant via U-14 ditch (Figure 4). This cooling water joins effluents from a laundry which enriches the pond with a cont inuous supply of phosphorus (Table 1). This is the smallest and most rapidly flushing of the Hanford ponds, and has relative high alkalinity and seston concentrations (Table 1). It contains transuranic elements and other actinides along with low-level quantities of mixed fission and activation products (Figure 4). The algal and macrophyte populations are the most diverse among Hanford systems (Tables 2 and 4). Although the periphyton populations appears relatively active (Table 3 ), unattached masses of green algae are most abundant in this pond. There is a diverse and moderately productive population of invertebrates (Tables 3 and 5 ), and the pond also supports a prolific goldfish population.

\section{Z-19 Ditch}

This ditch has carried aqueous wastes into U-Pond from plutonium processing and supporting laboratories in the 200-West Area since 1971 (Figures 1 and 4 ). Like earlier $Z$-ditches, this stream has received occasional releases of effluents containing actinides, including transuranics, and mixed fission and activation products (Figure 4). Such a release occurred in 1976, necessitating that the stream be reduced to $<10 \%$ of its previous flow rate. It contains relatively high seston, alkalinity, phosphate, and silicate concentrations, but has only small amounts of ammonia (Table 6). The variety of algae is relatively small (Table 2), and this population is dominated by a filamentous green alga growing attached to several types of densely populated macrophytes (Table 4). The variety, 


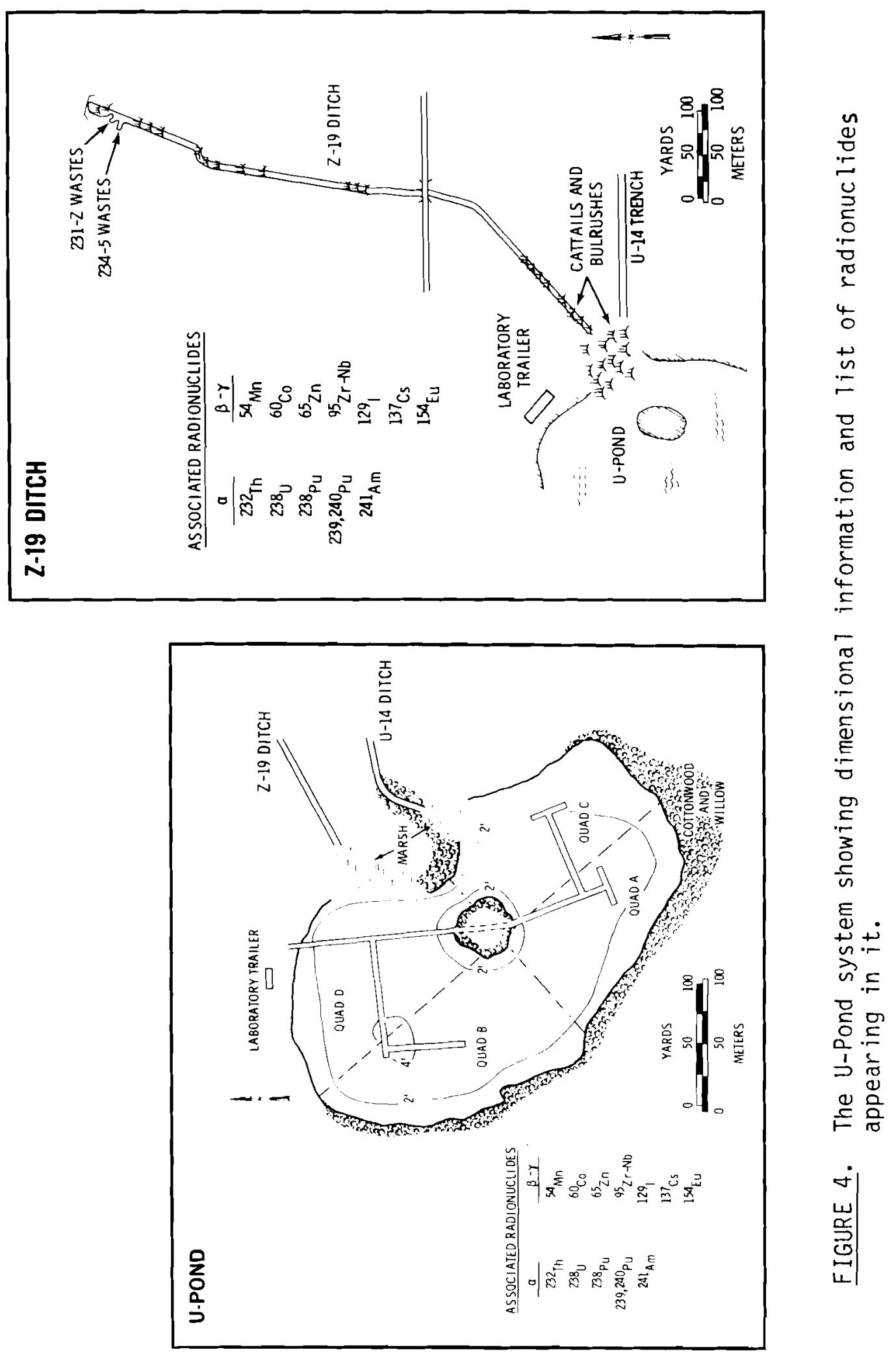


diversity, and colonization pressure of the invertebrate population is low compared to most other Hanford sites (Tables 3 and 5), and there is no fish life in this stream.

\section{0-N Trench}

This trench has received primary cooling water directly from the 1301-N crib at the $N$-reactor site since 1962-63 (Figures 1 and 5). In addition, it occasionally receives contaminates from the reactor following a fuel element failure. It contains mixed fission and activation products along with actinides, including transuranics (Figure 5). Concentrations of most of these nuclides are much greater than those appearing in other Hanford study sites. Its temperature range is also higher than those occurring at the

\section{0-N TRENCH}

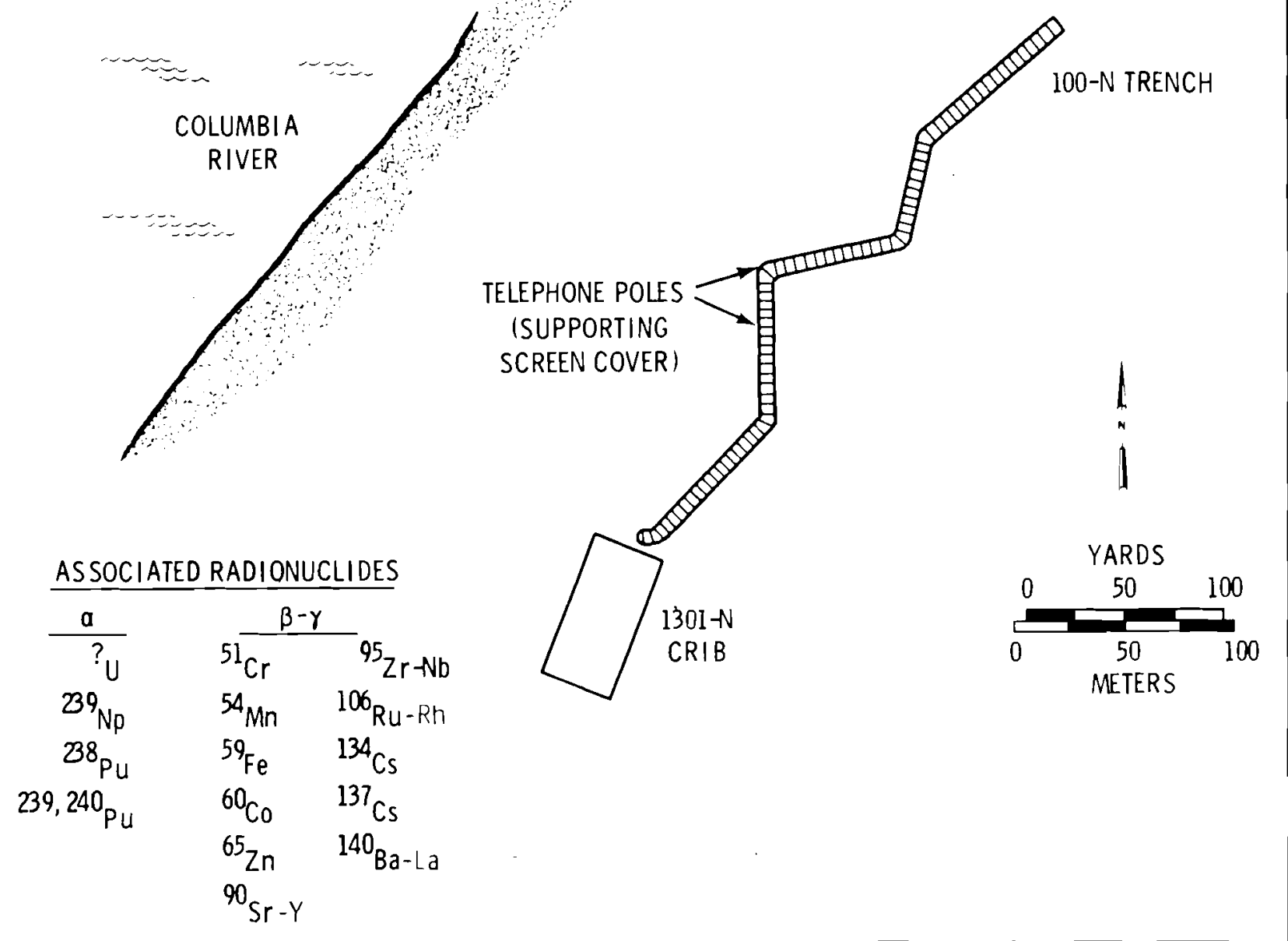

FIGURE 5. The 100-N trench shown with dimensional information and lists of radionuclides appearing in it. 
other sites (Table 6 ). The variety of algae is relatively low, but includes both periphytic and unattached filamentous forms (Table 2). The macrophyte population is very sparse (Table 4). The invertebrate population is relatively limited in variety (Table 5 ), but has moderate diversity and colonization pressure (Table 3 ). There is no fish life in this trench.

\section{RADIOLOGICAL CHARACTERISTICS OF PONDS AND STREAMS}

Data describing dose rates and water concentrations of radionuclides in these systems were examined by several approaches to determine which statistics best represent the similarities and differences among the study sites. Although it was difficult to establish reliable central tendencies for many of these data, due mainly to many samples having lower than detectable levels, we observed that maximum values recurred frequently enough to depict a reliable upper range of exposure. We concluded that maximum dose rates from the sediment and maximum concentrations of nuclides in water provided the best criteria for grouping these systems radiologically. These maxima also define upper limits of radiological conditions to which the biota that live in these systems are exposed.

When these aquatic systems are viewed in this way, they exhibit a broad spectrum of radiological conditions. At one extreme is $100-\mathrm{N}$ trench, with maximum nuclide concentrations of $>5 \times 10^{6} \mathrm{pCj} / \ell$ of water and $>7 \times 10^{5} \mathrm{mR} / \mathrm{Wk}$ dose from the sediment (Table 7 and Figure 6 , also see Appendix A, Radiological Parameters). At the other extreme is the B-Pond system, including $A-29$ and B-3 ditches, with maxima of $<8 \times 10^{2} \mathrm{pCi} / 2$ of water and $<10 \mathrm{mR} / \mathrm{wk}$ from the sediments. Gable Pond and U-Pond, including Z-19 ditch, show maximum water activity ranging between $10^{3}$ and $10^{7} \mathrm{pCi} / \ell$ and maximum dose rates from sediments ranging between $10^{2}$ and $10^{3} \mathrm{mR} / \mathrm{wk}$. Although Gable Pond has maximum dose rates that were equivalent to the U-Pond system, its maximum concentration of nuclides in the water is about two orders of magnitude lower and shows similarity to the B-Pond system (Table 7 and Figure 6). West Pond, conversely, shows a maximum activity concentration in water equivalent to that in Gable and U-Pond, but its maximum dose from the sediments is two orders of magnitude lower and, thus, similar to the B-Pond system. [Recall that West Pond has not been used as a waste handling facility and probably gets its radionuclide burden by evaporative 


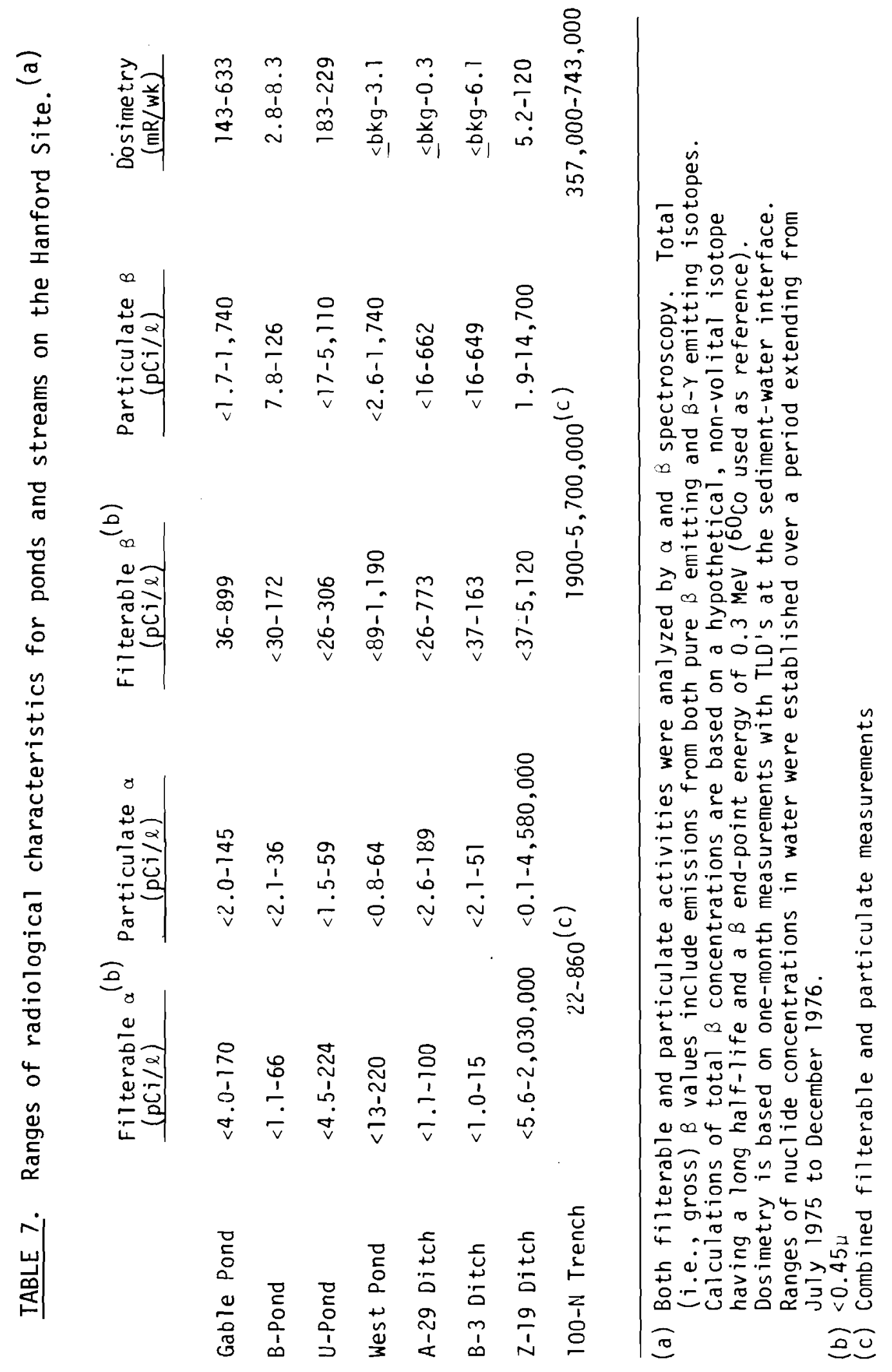




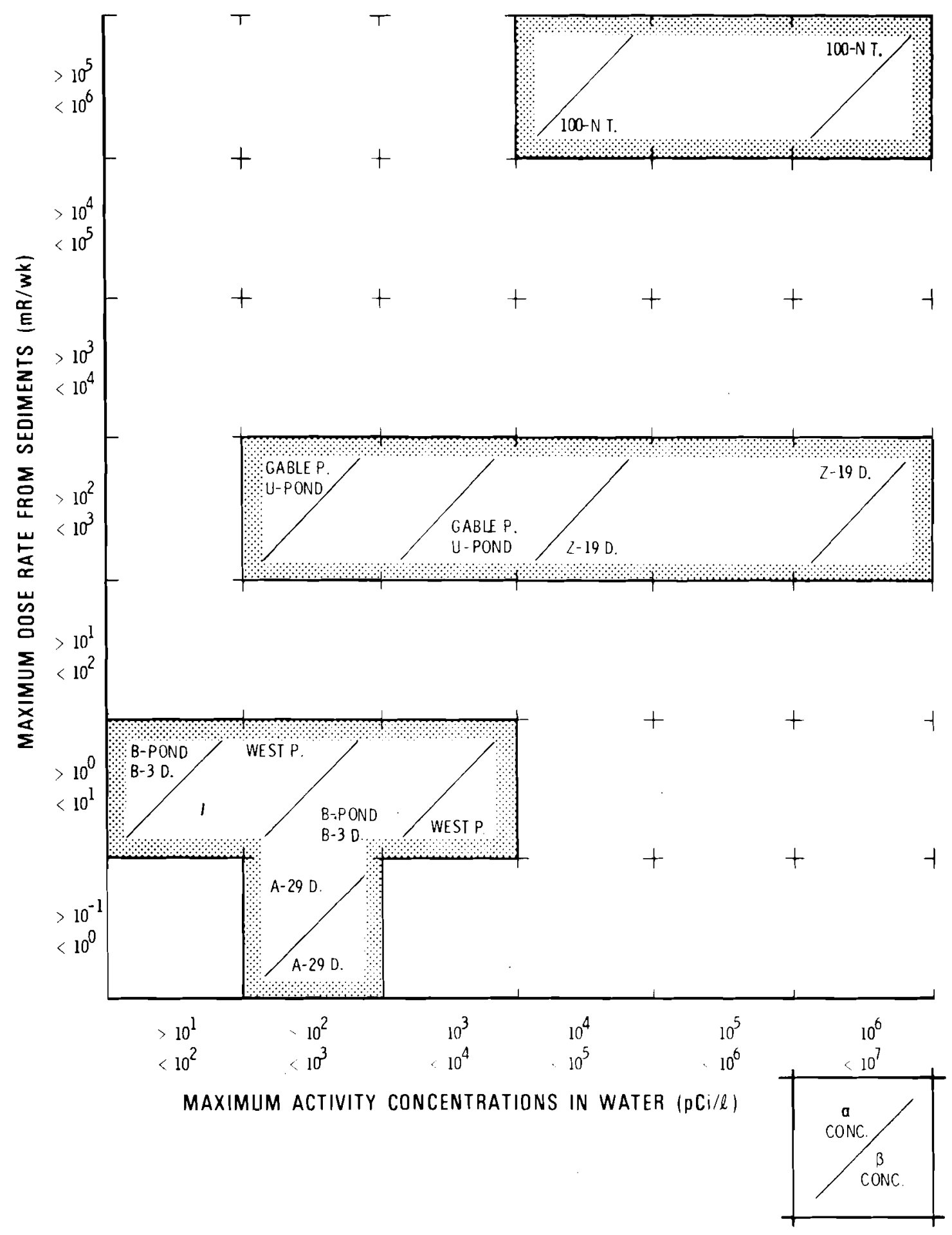

FIGURE 6. A matrix of maximum nuclide concentrations in water vs. maximum dose rates from sediments, used to suggest a relative grouping of the study sites on the basis of their radiological conditions. 
concentration of nuclides from the groundwater. A few analyses of West Pond water show that total uranium concentrations occur as $\mathrm{high}$ as $240 \mathrm{pCi} / \mathrm{l}$ (Larson, H. F., 1977, private communication, Battelle, Pacific Northwest Laboratories, Richland, WA).]

Concentrations of alpha activity in water are highest in Z-19 ditch (maximum of $4.6 \times 10^{6} \mathrm{pCi} / \ell$ ) where actinides, mainly transuranics, are present. Alpha radiation has very low penetration, hence, alpha emitting isotopes in the sediment do not produce a significant dose to organisms in overlying water. A11 other systems except for B-Pond and A-29 ditch have maximum concentrations of alpha emitters of about $10^{2} \mathrm{pCi} / \ell$ (Table 7 ).

Total nuclide concentrations are high in $100-\mathrm{N}$ trench water compared to the water of other systems (maximum $\sim 6 \times 10^{6} \mathrm{pCi} / \ell$ ). No other site has concentrations exceeding $2 \times 10^{4} \mathrm{pCi} / \ell$. However, the U-Pond system shows total $\beta$ concentrations of $5 \times 10^{3} \mathrm{pCi} / \ell$ in the pond and $1 \times 10^{4} \mathrm{pCi} / \ell$ in Z-19 ditch. There are indications that these $\beta$ emissions are from strontium and cesium deposits left by earlier waste discharges. West Pond has notable total $\beta$ activity in its water (maximum of $1 \times 10^{3} \mathrm{pCi} / \mathrm{l}$ ), which may be caused by the pond's uranium content. In spite of West Pond's relatively high total $\beta$ concentrations in the water, its dose rate from the sediments is relatively low ( $<4 \mathrm{mR} / \mathrm{wk}$, Table 7$)$. Gable Pond and A-29 ditch have maximum nuclide concentrations in water of approximately $1 \times 10^{3} \mathrm{pCi} / \ell$, while the remaining systems all have maximum concentrations below this level.

In grouping these systems radiologically for comparative purposes, it is obvious that $100-\mathrm{N}$ trench stands apart from the others. Hence, these systems can be grouped into two radiological categories having either low or high radioactive properties. A second option is to use three categories based on the three groups shown in Figure 6 . This would attempt to discriminate these systems on a relative basis of low, medium and high radioactive properties. It should be noted that while these 3 groupings are clearly separated in terms of maximum doses from sediments, there is considerable overlap in their maximum concentrations of nuclides in water. 


\section{DISCUSSION}

Since we are interested in determining if the nuclear wastes that enter these aquatic systems affect the colonization and productivity of biota, we will examine the ecological profiles of these ponds and streams in an attempt to identify variations that might be associated with the relative categories of contamination (Figure 6 ). Although the biological activity in these systems may show tolerance and sensitivities to nuclear wastes, they will also reflect conditions of habitat such as temperature, available substrate, flow rates, nutrient supply and other chemical conditions, and light penetration; none of which are unique to Hanford. Hence, common environmental factors that ordinarily limit and control biological activity will be superimposed over any variations in the biota that may be attributed to the presence of nuclear wastes. This will reduce the resolving power of our assessment and may prevent definitive conclusions about relationships between rad-wastes and ecological processes. If we cannot establish such relationships using these aquatic systems, then we must conclude that our indicators lack sufficient sensitivity or that higher levels of contamination are needed to demonstrate effects in these types of freshwater environments.

ECOLOGICAL VARIATION IN HANFORD SYSTEMS

Algal populations are predominately periphytic in all systems except U-Pond and 100-N trench (Table 2). These systems support relatively abundant masses of unattached $f i l$ amentous green algae. Blue-green algae appear in all systems showing a moderate relative abundance. Of these, Oscillatoriaceae are the most prominant. Green algae are we 11 represented in all systems. Forms of desmid, oöcystacean and filamentous green algae are found at all sites. Euglenoids and dinoflagellates appear only in U-Pond and West Pond. Diatoms are moderately abundant in all systems. The more frequently occurring diatoms belong to the families Coscinodiscaceae, Naviculaceae, Cymbellaceae, and Fragilariaceae. Cryptomonads are found in moderate quantities in most ponds and some ditches. The variety of algae in Z-19 ditch and 100-N trench is reduced in comparison to the other systems. 
These sites have the highest maximum nuclide concentrations in water but are several orders of magnitude apart in terms of maximum dose rates from the sediment (Figure 6).

Mean rates with which periphyton populations colonize bare substrates

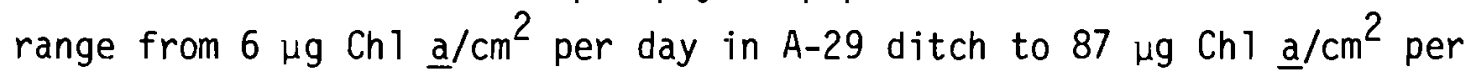
day in B-3 ditch, and mean rates among ponds range from 17 to $73 \mu \mathrm{g} \mathrm{Ch} 1$ a $/ \mathrm{cm}^{2}$ per day (West Pond and B-Pond respectively, Table 3 ). The variation of these periphyton colonization rates does not suggest an association with the relative categories of contamination in Figure 6 . Furthermore, these rates are similar to those measured by the same method in Lake Sammamish and several of its tributaries located in western Washington. The mean colonization rate for these streams was $32 \mathrm{ug} \mathrm{Ch} 1$ a $/ \mathrm{cm}^{2}$ per day, while the lake's periphyton population colonized a bare substrate at a mean rate of only $1 \mu \mathrm{g} \mathrm{Chl} \mathrm{a/} / \mathrm{cm}^{2}$ per day (Emery et al., 1973). (It is not unreasonable to find periphyton colonization pressure in a large lake to be less than that in a pond.) We conclude that while the colonization activity of algae in Hanford aquatic systems does not show variations that correlate with nuclear waste content, the variety of algae appears to be reduced in the two systems with the highest radioactive content, $100-\mathrm{N}$ trench and $\mathrm{Z}-19$ ditch.

Results of macrophyte surveys show that some form of vascular plant is found in every system (Table 5). Bulrushes (Scirpus) appear in all systems and cattails (Typha) appear in most. Gable Pond, U-Pond and Z-19 ditch have the greatest variety and relative abundance of macrophytes. Cottonwoods (Populus) appear around Gable Pond, A-29 ditch and the U-Pond system.

Pondweed (Potamogeton) appear in a 11 ponds except West Pond and speedwell (Veronica) appear in all streams. Horsetail (Equisetum) was observed at Gable and U-Pond, and hornwort (Ceratophyllum) and water milfoil (Myriophyllum) are found only in Gable Pond. Duckweed (Lemna), smartweed (Polygonum) and willows (Salix) were observed only at U-Pond. Watercress (Rorippa) and wild lettuce (Lactuca) appear in U-Pond and Z-19 ditch.

The general appearance of macrophytes in these systems indicates that 100-N trench is deficient in vascular plant populations when compared to the rest. However, this trench appears to be a poor habitat for macrophytes because of light limitations and higher temperatures. Cooling water from 
the 1301-N crib is discharged directly into $100-\mathrm{N}$ trench causing its temperatures to frequently raise more than $8^{\circ} \mathrm{C}$ above temperatures of other systems. Also, the steep embankments and protective screen, which collects tumbleweeds, reduces available light needed for macrophyte growth. Therefore, we conclude that the relative deficiency of macrophytes in $100-\mathrm{N}$ trench could easily be attributed to physical factors. Hence, it is not yet possible to determine if the radioactive materials are significantly involved in the reduced variety and abundance of macrophytes in $100-\mathrm{N}$ trench.

Invertebrates that are commonly found in many smaller freshwater environments also appear in Hanford aquatic systems (Table 5). Along with a variety of insects, an assortment of flatworms, segmented worms, crustaceans, arachnids, snails, and goldfish were found in many of these sites. All systems support populations of segmented worms (01igochaeta) and midge larvae (Chironomidae). In addition to chironomids, the most frequently observed insects were mayfly larvae (Baetidae), the dragonflies Aeschna and Libellula and the damselfly Ischnura, waterstridders (Gerridae), backswimmers (Notonectidae), waterboatmen (Corixidae), caddisfly larvae (Tricoptera), and predaceous diving beet les (Dytiscidae).

The ponds (except West Pond) are more richly populated with aquatic fauna in terms of variety and relative abundance than the streams. U-Pond, in particular, appears to have the most complete culture of aquatic animal 1ife. West Pond, due to its discriminating chemistry, has fewer numbers and a smaller variety of animal life, resembling the invertebrate populations occurring in Hanford streams. The variety of invertebrates in A-29 ditch is also relatively smaller and may have been limited by chemicals that are occasionally discharged into this stream. The two systems with highest doses from the sediments and nuclide concentrations in the water (100-N trench and Z-19 ditch) support relatively smaller varieties of invertebrates. However, varieties of these invertebrate populations are not significantly less than those in West Pond or A-29 ditch. Since all four systems appear to have unusual physicochemical and/or radiological conditions, this general reduction in variety appears to indicate an association with factors of environmental stress and limitation. 
Mean invertebrate colonization rates are highest in Gable Pond and B-3 ditch ( 1020 and 1610 organisms $/ \mathrm{m}^{2}$ per day, respectively) and lowest in Z-19 ditch, West Pond and A-29 ditch (<100, 188 and 275, respectively, Table 3). While Z-19 ditch had very weak colonization pressure, the mean rate of invertebrate colonization in $100-\mathrm{N}$ trench $\left(897\right.$ organisms $/ \mathrm{m}^{2}$ per day) was higher than those occurring in most ponds and much higher than those in 2 of the ditches. A-29 ditch appears least able to support invertebrate life, and since this ditch is the least contaminated of our study sites, we attribute this relatively small population of invertebrates to the intermittent discharges of nonradiological wastes that appear to limit colonization and growth of biota. The system having the highest temperatures and greatest content of radioactive materials, 100-N trench, supports an insect population with more variety and productivity than some systems with much lower levels of contamination.

Indicators of community diversity based on these insect populations show that ponds generally have higher diversity than streams (Table 3 ). For ponds, mean community diversity $\left(H^{\prime}\right)$ ranged from 1.2 (West Pond) to 2.1 (Gable and U-Pond). Mean $H^{\prime}$ for streams ranged from 0.1 in B-3 ditch to 0.9 in 100-N trench, although $100-\mathrm{N}$ trench appears to be more of a lentic environment than the ditches. These ranges of $H^{\prime}$ are similar to that observed in the Columbia River during 1975-1977 (0.4 - 1.8, Page and Neitze1, 1977).

In comparison to offsite environments, the range of $H^{\prime}$ in Hanford aquatic systems is more reduced than those in an Ohio stream $(0.3-3.5$, Egloff and Brakel, 1973) or those in an Ok lahoma stream receiving domestic and oil refinery effluents $\left(0.3-3.4\right.$, Wilhm and Dorris, 1966). These $H^{\prime}$ ranges can also be compared to the results of a survey made by Wilhm (1970) in several regions of the United States. After studying ranges of diversity indices in some mid-western, western, and south-eastern streams, he concluded that polluted streams usually have $H^{\prime}<1$, while $H^{\prime}$ varies between 3 and 4 in clean-water streams. While $H^{\prime}$ values in Hanford ponds fall between 
these two extremes, Hanford streams could be ranked in the polluted category on the basis of their $H^{\prime}$ data, assuming that this comparison is valid. (b)

The evenness with which invertebrates are distributed among the families (mean $J^{\prime}$ ) in Hanford systems is generally higher in ponds $(0.5$ 0.8$,$) than in streams (0.04-0.5$, Table 3$)$. Evenness of the Columbia River invertebrate population ranged from 0.1 to 0.6 (Page and Neitze1, 1977), and 0.3 to 0.7 in an Ohio stream (Egloff and Brake1, 1973). In making these comparisons, it should be pointed out that the richnesses (i.e., number of taxa of invertebrates) in these systems were considerable higher than those of Hanford study sites. Richness indices (s, Table 3) for Hanford study sites ranged from 0 to 8 , while those in the Columbia River ranged from 4 to 13, those in an Ohio stream from 8 to 29 , and those in an Ok lahoma stream from 2 to 18 .

Goldfish populate Gable Pond, U-Pond and B-Pond, and B-3 ditch. Only U-Pond and Gable Pond have large populations of goldfish. Population estimates have been made only in U-Pond, showing a maximum production rate of about $40 \mathrm{~kg} /$ hectare per day. This falls within production ranges for suckers and carp reported by Carlander (1955) for a number of North American freshwater systems.

The general appearance of animal life in the Hanford study sites does not indicate an association with our grouping of these systems in terms of nuclide concentration and dose, although there is a weak suggestion that variety of invertebrate populations may be reduced by higher levels of radioactivity. However, we also observed that some aquatic systems with

(b) When comparing our diversity expressions with those obtained by other investigators, we recognize that the taxonomic level defining richness (s) may not be consistent among all studies. For our study, we specify $s$ at the family level, while other studies may use a different taxonomic level to define s. Some studies may even use several taxonomic levels for s determinations, depending upon the extent of identification carried out for any particular organism. The use of the lowest common taxon is prefered over multiple taxa for specifying $s$ because the $H^{\prime}$ equation was developed for one common level of taxonomic grouping, not for several grouping arrangements factored into the same H'calculation. Since we use the family level as the lowest common taxon, our $\mathrm{H}^{\prime}$ expressions may be more conservative than others obtained through using a lower taxon or several taxa in combination. 
lesser amounts of radioactivity have reductions in the variety in their invertebrates which may be associated with harsh chemical conditions. Data for other parameters do not indicate an association between the diversity and productivity of animal life and the relative amounts of nuclear wastes. The colonization pressure of the invertebrate population in $100-\mathrm{N}$ trench was greater than three of the ponds and two of the other streams. Ranges of community diversity indices for Hanford systems are similar to those found in the Columbia River, but are somewhat lower than those in offsite reference streams. Hence, conditions of natural habitat may provide a better explanation for these differences than the presence of nuclear wastes.

\section{EFFECTS OF IONIZING RADIATION OBSERVED IN OFFSITE ENVIRONMENTS}

Since our study has not produced conclusive evidence that aqueous nuclear wastes have affected the biota in Hanford ponds and streams, we will explore the possibility that these levels of contamination are insufficient to impact the colonization, variety and productivity of aquatic life occurring in these systems. Although there are no data that relate levels of radioactive contamination to effects measured in aquatic ecosystems, information is available that describes damage from ionizing radiation to some aquatic organisms and terrestrial communities.

Ranges of ionizing radiation that caused limited damage to aquatic life are summarized and reported by Polikarpov (1966) and IAEA (1976). These data are expressed as amounts of radiation received by a variety of aquatic organisms over specified periods of time, and many of these results are based on short-term exposures (i.e., 7 to 75 days). In order to compare these dose rates to those occurring in Hanford systems, we will express a 11 radiation doses in terms of $\mathrm{R} /$ day. This assessment will focus on levels of radiation that produce only 1 imited effects in biota. Higher dose rates will obviously be lethal to the biota and will not identify the minimum levels of radiation needed to damage living systems.

Dose rates of ionizing radiation having limited effects on freshwater algae range from 50 to $1700 \mathrm{R} /$ day (Figure 7). The genera of algae for. which dose effects are reported were found in most Hanford study sites, including. 100-N trench. Freshwater invertebrates begin to show damage from doses 
RANGES OF DOSES OBSERVED IN HANFORD AQUATIC SYSTEMS:

A-29 DITCH

WEST POND

B-3 DITCH

B-POND

Z-19 DITCH

U-POND

GABLE POND

1OO-N TRENCH

RANGES WI THIN WHICH LIMITED DAMAGE (MINOR TO INTERMEDIATE) HAS BEEN OBSERVED:

AQUATIC ORGANISMS

(POLIKARPOV 1966 AND IAEA 1976):

ALGAE

INVERTEBRATES

$\mathrm{FISH}$

AMPHIBIANS

TERRESTRIAL COMMUNITIES

(WHICKER AND FRALEY 1974):

CONIFEROUS FOREST

DECIDUOUS FOREST

SHRUB

GRASSLAND

MOSS-LICHEN

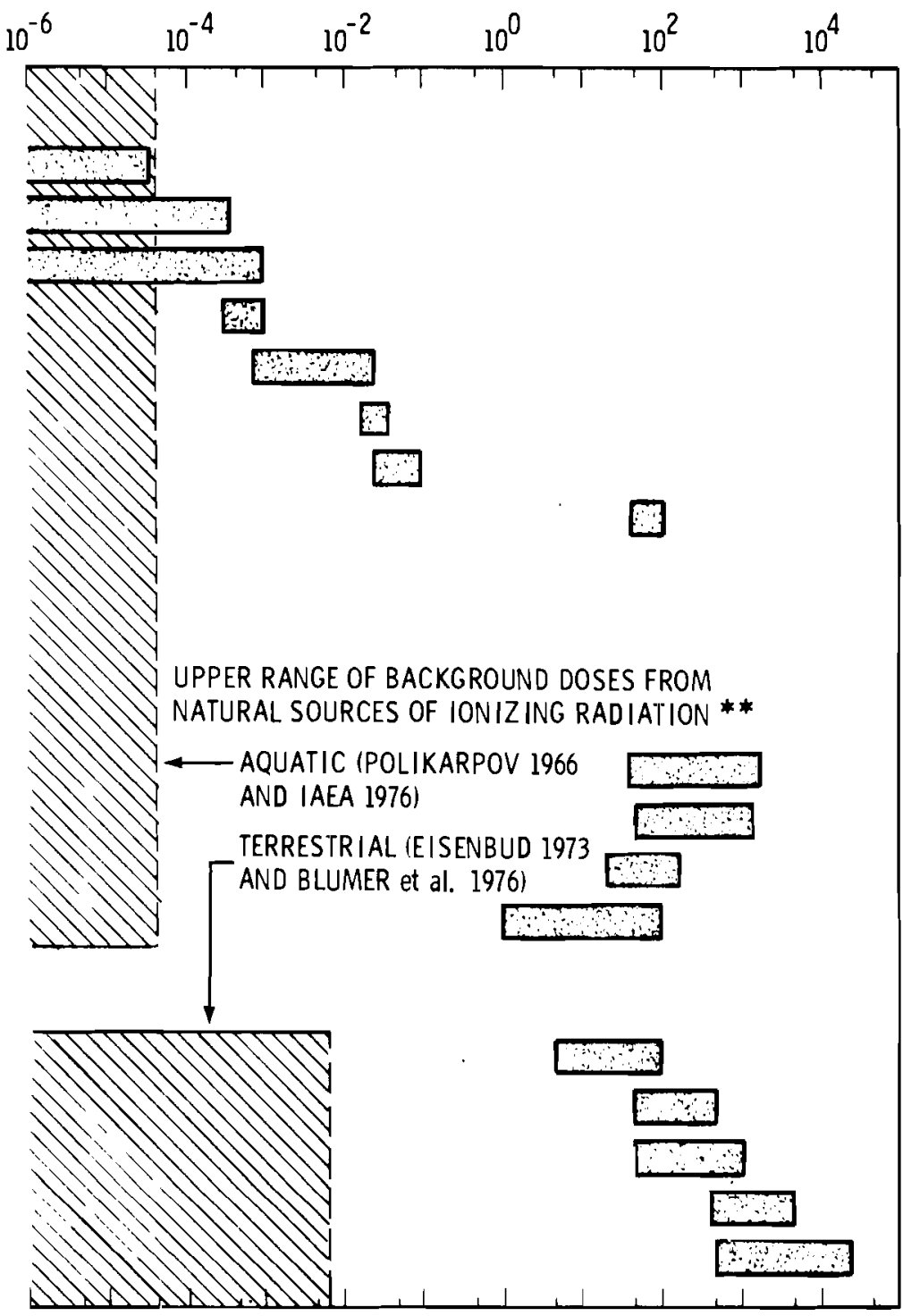

* ASSUME rad $\approx \mathrm{R}$

** DOSE FROM INTERNAL EMITTERS INCLUDED, ALPHA DOSE EXCLUDED

FIGURE 7. A comparison of doses of ionizing radiation at the sediment-water interface of Hanford aquatic systems with doses observed to cause minor to intermediate damage in aquatic organisms and terrestrial communities. 
ranging from 60 to $1100 \mathrm{R} /$ day. Nearly all of these genera are found in most Hanford ponds and streams, but of the invertebrates for which dose effects data are reported, only snails are found in $100-\mathrm{N}$ trench. Freshwater fishes, including the genera Carassius (goldfish), Oncorhynchus (salmon), and Salmo (trout), showed limited damage from radiation within a range of 20 to $120 \mathrm{R} /$ day. Carassius has thrived in Gable Pond, B-Pond and B-3 ditch, and U-Pond for many years, but it is doubtful that goldfish have ever been introduced into $100-\mathrm{N}$ trench. Amphibians are reported to begin to show damage by doses in the range of 1 to $100 \mathrm{R} /$ day. This indicates that they are the most sensitive to radiation among those freshwater organisms for which there are data. Although amphibian life is not frequently observed in Hanford aquatic systems, a small cluster of tadpoles was found in U-Pond in 1974.

These data describing minimum amounts of radiation required to produce effects on aquatic biota indicate that damage may be caused by doses in the range of from 1 to $1700 \mathrm{R} /$ day (Figure 7). All Hanford study sites have doses from the sediment that fall below this range $(<0.1 \mathrm{R} /$ day $)$, except 100-N trench which shows dose rates ranging from 50 to $100 \mathrm{R} /$ day. Therefore, these findings suggest that on ly 100-N trench has levels of radiation that could perhaps limit the colonization and growth of aquatic life.

Effects of ionizing radiation on terrestrial communities have been summarized and reported by Whicker and Fraley (1974). These data indicate that a coniferous forest is the most sensitive to radiation among terrestrial communities, showing minor to intermediate damage from dose rates ranging from 5 to $100 \mathrm{R} /$ day (Figure 7 ). The most tolerant of these was the moss-lichen community, showing limited damage from doses ranging from 500 to $25,000 \mathrm{R} /$ day. Hence, these radiation-effects data indicate that terrestrial communities will begin to show limited damage from dose rates that roughly coincide with those rates required to cause limited effects in aquatic organisms. However, $100-\mathrm{N}$ trench has dose rates that are similar only to those ranges of dose affecting coniferous forest, deciduous forest, and shrub communities (Figure 7). Grassland and moss-1ichen communities are not apparently damaged by levels of radiation found in $100-\mathrm{N}$ trench. 
It is worth noting here that the more primitive terrestrial communities appear to have greater tolerance to radiation than the more highly evolved plant life of the shrub, deciduous, and coniferous communities. The same appears to be true for aquatic organisms; the lesser evolved algae and invertebrates show greater tolerance to radiation than the more advanced fish and amphibians.

This comparison of susceptibilities to radiation by aquatic organisms and terrestrial communities may provide an explanation for the ability of $100 \mathrm{~N}$ trench to support a moderate diversity of aquatic life despite its potentially harmful levels of radiation. The radiation from 100-N trench sediments may be prohibitive to some, but certainly not all, aquatic organisms. Biota that develop communities in 100- $\mathrm{N}$ trench represent lower forms of evolutionary advancement and can tolerate these higher levels of radiation. These same organisms are common to most smaller freshwater environments and also appear in the other Hanford aquatic systems. Therefore, it becomes more difficult to differentiate $100-\mathrm{N}$ trench from the other systems on the basis of biota appearing in them, and as a result, our study does not produce clear evidence at either the community or the organismic level that these quantities of nuclear wastes affect the occurrence and growth of aquatic life. 


\section{SUMMARY AND CONCLUSIONS}

This study has generally characterized the limnological and radiological conditions that exist in aquatic environments on the Hanford Site (excluding the Columbia River) and attempted to determine if nuclear waste discharges can be related to ecological variation among these systems. All study sites have received wastes directly from nuclear facilities except west Pond, which is included in this investigation because of its natural accumulation of radioactivity and its interesting limnology.

The aquatic systems that were studied include Gable Pond and West Pond located in the 200-North Area near Gable Mountain; the B-Pond system near the 200-East Area, including B-3 and A-29 ditches; the U-Pond system inside the 200-West Area, including Z-19 ditch; and 100-N trench which lies near the $100-\mathrm{N}$ reactor site.

Along with a short historical description, each system is assessed in terms that describe its physical, chemical and biological limnology and its general radioactive character expressed as doses from the sediments and concentrations of $\alpha$ and $\beta-\gamma$ nuclides in the water. Maximum dose rates and nuclide concentrations are used to group these systems into three categories differentiated by relative content of nuclear wastes. The B-Pond system and West Pond fall into the lowest category of nuclear waste content, while $100-\mathrm{N}$ trench alone represents the highest category. A mid-range grouping is suggested by Gable Pond and the U-Pond system, although these systems show considerable overlap with those in the other groups in terms of maximum activity in water. Finally, literature resources are used to identify minimum levels of radiation that have been shown to be harmful to some aquatic organisms and terrestrial communities. The range of radiation dose observed to be marginally damaging to these biological systems was compared to the measured levels of radiation in the Hanford ponds and streams to determine if radiation from nuclear wastes in these systems is sufficent to affect the aquatic communities that colonize them.

A11 systems support populations of commonly occurring algae, macrophytes, invertebrates, and in some cases, fish. Although the variety in algal populations is reduced in $100-\mathrm{N}$ trench and $\mathrm{Z}-19$ ditch, variety in 
other types of biota is not. Community structures in these systems appear to be as diverse as those in the Columbia River but occasionally less diverse than in some offsite-reference streams. The productivity of plant life, invertebrates and fish in these systems does not appear to be associated with the relative amounts of nuclear waste contamination. Furthermore, their rates of productivity resemble those measured in aquatic environments not associated with nuclear activities. In terms of the parameters studied, we find no conclusive evidence that the radionuclides discharged into Hanford ponds and streams have affected the colonization, diversity, and activity of biota that appear in them.

Despite this lack of ecological evidence, we have determined from the 1 iterature that one system (100- $\mathrm{N}$ trench) contains enough radiation to be potentially harmful to some aquatic organisms and terrestrial communities. However, this ecosystem does not give clear indication that its biota are influenced by this radiation. We recognize that the organisms existing in the radiation from 100- $\mathrm{N}$ trench sediments are common to most smaller freshwater environments and also appear in other Hanford aquatic systems. Therefore, these nuclear waste ponds and streams cannot be differentiated between offsite systems or among themselves on the basis of a comprehensive biological profile. 


\section{REFERENCES}

American Public Health Association, and others. 1976. Standard Methods for the Examination of Water and Waste Water. 14th ed. APHA, Washington, D.C., $874 \mathrm{pp}$.

Atlantic Richfield Hanford Company. 1975 and 1976. Week ly Analytical Report of Radiation Monitoring Samples ARHCO 222-S Analytical Reports, Atlantic Richfield Hanford Co., Richland, WA.

Blumer, P., P., J. J. Fix and D. R. Speer. 1976. Environmental Surveillance at Hanford for CY-1975 Data. BNWL-1980, Battelle, Pacific Northwest Laboratories, Richland, WA.

Carlander, K. D. 1955. The standing crop of fish in lakes. Jour. Fish Res. Bd. Can. 12:543-570.

Cucchiara, A. L. 1976. 1975 Environmental Release Report. United Nuclear Industries Inc. Reactor and Fuel Production Facilities, UNI-544. NTIS, Springfield, VA.

Egloff, D. A. and W. H. Brakel. 1973. Stream pollution and a simplified diversity index. J. Water Pollution Control Fed., 45:2269-2275.

Eisenbud, M. 1973. Environmental Radioactivity. 2nd ed., Academic Press, New York.

Emery, R. M., C. E. Moon and E. B. Welch. 1973. Enriching effects of urban runoff on the productivity of a mesotrophic lake. Water Res. 2:1506-1516.

Einery, R. M. and T. R. Garland. 1974. The Ecological Behavior of Plutonium and Americium in a Freshwater Ecosystem: Phase II Implications of Differences in Transuranic Isotopic Ratios. BNWL-1879, Battel1e, Pac if ic Northwest Laboratories, Richland, WA, $26 \mathrm{pp}$.

Emery, R. M., D. C. Klopfer, T. R. Garland and W. C. Weimer. 1976. The ecological behavior of plutonium and americium in a freshwater pond. In: Radioecology and Energy Resources, Proc. Fourth National Symposium on Radioecology, Corval1is, Oregon 12-14 May, 1975. (C. E. Cushing, ed.) pp 74-85. Halsted Press, New York.

Emery, R. M., D. C. Klopfer and M. C. McShane. 1978. The ecological export of plutonium from a reprocessing waste pond. Health Phys. 34:255-269.

Hester, F. E. and J. S. Dendy. 1962. A multiple-plate sampler for aquatic macroinvertebrates. Trans. American Fisheries Soc., 91:420-421. 
International Atomic Energy Agency. 1976. Effects of Ionizing Radiation on Aquatic Organisms and Ecosystems. IAEA Tech. Rep. Series No. 172., IAEA/Vienna.

Page, T. L. and D. A. Neitzel. 1978. Aquatic Ecological Studies Conducted Near WNP 1,2 and 4, January 1977 through December 1977. Battelle, Pacif ic Northwest Laboratories to United Engineers and Constructors for Washington Public Power Supply System, Vol. $5 \mathrm{sec}$. 4, WPPSS, Richland, WA. (in press).

Pielou, E. C. 1967. The use of information theory in the study of diversity of biological populations. In: Proc. 5 th Berkeley Symp. on Math. Stat. and Prob. vd 4, pp 163-177. University of California, Berkeley, CA.

Polikarpov, G. G. 1966. Radioecology of Aquatic Organisms. North-Holland Pub. Co. - Amsterdam and Reinhold Book Div., New York.

Robbins, W. W., T. E. Weier and C. R. Stocking. 1957. Botany: An Introduction to Plant Science, John Wiley and Sons, Inc., New York. $204 \mathrm{pp}$.

Strickland, J. D. H. and T. R. Parsons. 1972. A Practical Handbook of Seawater Analysis. 2nd ed., Bul1. Fish. Res. Bd. Can. Ottawa, 309 pp.

Verduin, J. 1964. Principles of primary productivity: Photosynthes is under completely natural conditions; In: Algae and Man, (D. F. Jackson, ed.) 221-228. Plenum Press, New York.

Whicker, F. W. and L. Fraley, Jr. 1974. Effects of ionizing radiation on terrestrial plant communnties. Adv. Radiat. Biol. 4:317-366.

Wilhm, J. L. 1970. Range of diversity index in benthic macroinvertebrate populations. J. Water Pollution Control Fed., 42(5, Pt. 2):R221-R224.

Wilhm, J. L. and T. C. Dorris. 1966. Species diversity of benthic macroinvertebrates in a stream receiving domestic and oil refinery eff luents. The American Midland Naturalist, 76:427-4.49. 
APPENDIX A

METHODS AND MATERIALS 


\section{PHYSICAL PARAMETERS}

This study was conducted from November 1975 to June 1977.

Planar measurements of ponds and streams were made using aerial photographs and ground-based linear indicators. Volumes of ponds were determined from surface measurements and depth sounding data taken along transects. Hydraulic retention times for ponds were determined by dividing the volume of the pond by the mean stream inflow rate. Stream flow measurements were made using a General 0 ceanics ${ }^{(a)}$ current meter placed at regular intervals across the stream. Velocity readings were integrated across the vertical plane of the transect to determine rate of flow in the stream. Temperatures were monitored with Foxboro thermographs. Insolation data were obtained from the Atmospheric Sciences Department of Battelle-Northwest. Seston concentrations were determined by filtering known volumes of water through pre-weighed glass pads $(0.1 \mu)$ and then weighing the desiccated pads and residue. Sedimentation rates were either calculated from seston concentrations and water budget data or measured directly using sedimentation pans.

\section{CHEMICAL PARAMETERS}

Measurements of pH were made using a Leeds \& Northrup (Model No. 7417) pH meter. Dissolved oxygen was measured with YSI (Mode1 51A) D0-temperature probe and meter. Alkalinity and hardness were determined by titration methods described by APHA et al. (1976). Conductivity was measured using an Industrial Instrument Mode 1 RC-16B conductivity bridge.

Nitrate and nitrite nitrogen concentrations were determined by the cadmium-copper reduction method (Strick land and Parsons, 1972). Ammonia and nitrogen were measured using the nesslerization technique (APHA et al., 1976). Concentrations of ortho- and total phosphates and total reactive silicates were determined by the molybdate complexing reaction (Strickland and Parsons, 1972).

$\overline{(a)}$ Use of trade names does not imply product endorsement by PNL or DOE. 


\section{BIOLOGICAL PARAMETERS}

Pond-wide primary productivity, determined for U-Pond only, was estimated using a method described by Verduin (1964) which accounts for the photosynthesis of all plant life in the pond per unit time and is inclusive of phytoplankton, macroalgae, and submerged macrophytes. Results of these measurements express the net rate of carbon assimilated by plants.

Rates of periphyton colonization (herein referred to as "colonization pressure") were estimated by measuring the maximum rates of chlorophy11 a accumulation on a $6.5 \mathrm{~cm}^{2}$ glass substrate over 4-week periods. Chlorophy 11 a was analyzed fluorometrically using the procedure described by Strickland and Parsons (1972).

To determine the colonization pressure of the invertebrate populations, colonization rates of sessile invertebrates were measured using lucite substrates. Substrate design resembled a Dendy trap (Hester and Dendy, 1962) but was constructed in the form of a cylinder of $0.64 \mathrm{~cm}(1 / 4 \mathrm{in.})$ thick circular lucite plates alternating between diameters of $7.5 \mathrm{~cm}$ and $2.0 \mathrm{~cm}$. A complete unit included 7 large and 6 small plates, providing a colonizing surface area of $886 \mathrm{~cm}^{2}$. Numbers of macroinvertebrates (minimum length of $2 \mathrm{~mm}$ ) appearing on these substrates in 1-week intervals over a period of 4 weeks provided an estimate of colonization pressure or potential.

Goldfish production was estimated for U-Pond only. Since the goldfish population appears to reproduce annually and undergoes substantial depletion in the colder months, a valid expression of annual production can be based on the summer standing crop. This standing crop was estimated by first establishing an average weight for an individual and then counting numbers or individuals appearing in 125 grids placed randomly about the pond. Each grid had an area of $9 \mathrm{~m}^{2}$. The mean number of individuals was converted to mean weight per unit area and proportioned to the entire pond area.

The ecological complexity and stability of macroinvertebrate communities were assessed using the diversity expression defined by Shannon (Pielou, 1967). Community diversity, expressed as per individual, was calculated using the equation 


$$
H^{\prime}=-\sum_{i=1}^{s} \frac{n_{i}}{N} \log _{2} \frac{n_{i}}{N},
$$

where $\mathrm{n}$ is the number of individuals in taxon s (richness), and $\mathrm{N}$ is the total number of individuals in the sample. The family level of taxonomic identification is used to specify s (see footnote on p. 24). The evenness (J) with which the individuals are distributed among the taxa is expressed using the equation

$$
J^{\prime}=\frac{H^{\prime}}{H^{\prime}} \text { max },
$$

where

$$
H_{\text {max }}^{\prime}=-\frac{\left(\bar{n} \cdot \log _{2} \frac{\bar{n}}{N}\right) s}{N}
$$

and $\bar{n}$ is the average of individuals per taxon.

These diversity indices were established by collecting macroinvertebrates from both sides of $1 \mathrm{~m}^{2}$ burlap sheets submerged at a study site for 1 month. (It was not possible to collect sufficient numbers and varieties of invertebrates from natural substrates in these aquatic systems.)

Collections of algae for taxonomic identification were made from the same glass substrates that were used for chlorophyll a determinations. Macrophytes collected directly from the study sites represent only the most frequently occurring aquatic and riparian vegetation. 


\section{RADIOLOGICAL PARAMETERS}

Ranges of filterable and particulate $\alpha$ and $\beta$ concentrations in the water of these study sites (except $100-\mathrm{N}$ trench) were determined from week ly analytical laboratory reports provided by the Atlantic Richfield Hanford Company (ARHCO, 1975-76). Samples of water were collected routinely at ARHCO's environmental monitoring stations, filtered through a $0.45 \mu$ membrane filter, and both filtrate and residue were analyzed by $\alpha$ and $\beta$ spectroscopy. Total (i.e., gross) $\beta$ analyses measured $\beta$ emissions from both pure $\beta$ emitting and $\beta-\gamma$ emitting isotopes. Calculations of total $\beta$ concentrations are based on a hypothetical, nonvolatile isotope having a long half-life and $a$ B end-point energy of $0.3 \mathrm{MeV}$. The reference isotope for these calculations is ${ }^{60} \mathrm{Co}$. Concentrations of $\alpha$ and $\beta$ activity in 100-N trench were determined in the same way on a monthly basis by United Nuc lear Industries and reported by Cucchiara (1976). Dose rates were determined at the sediment water interface using thermoluminescent $\mathrm{LiF}_{2}$ dosimeters (TLD's). Thermoluminescence was measured with a Harshaw Model 2000A analyzer coupled to a CI Model 1491 counter. 
APPENDIX B

DETAILED HISTORICAL AND ECOLOGICAL DESCRIPTIONS OF HANFORD PONDS AND STREAMS 


\section{GABLE POND}

Gable Pond lies to the south of Gable Mountain in the 200-North Area and is the largest of the Hanford ponds (Figures 1 and 2 ). It was created in 1957 to receive cooling water from a Purex Plant in the 200-East Area where reactor fuels were processed. It contains low-level quantities of actinides and mixed fission products $(<50 \mathrm{pCi} / \mathrm{ml})$ which entered the pond in 1964 following a rupture in the cooling coils at the Purex Plant.

Gable Pond has a surface area of $287,300 \mathrm{~m}^{2}$ (71 acres), a mean depth of $1.5 \mathrm{~m}(4.9 \mathrm{ft})$, and a volume of $431,000 \mathrm{~m}^{3}$ (350 acre-ft, Table 1). It receives water from the Purex Plant through a pipe line at a mean rate of $14 \mathrm{~m} / \mathrm{min}(3,700 \mathrm{gal} / \mathrm{min})$. Its retention time is approximately $500 \mathrm{hr}$ (Table 1). Water leaves the pond mainly through percolation, but when the pond level rises, water may exit via a spillway at its northwest end.

Most algal forms in Gable Pond are periphytic and are represented by numerous families of blue-green algae (Cyanophyta), green algae (Chlorophyta) and diatoms (Chrysophyta, Table 2). Euglenoid algae, dinoflagellates and Cryptomonads were not detected. This periphyton population colonized a bare substrate at a mean rate of $48 \mu \mathrm{g} \mathrm{Ch} 1 \underline{\mathrm{a}} / \mathrm{m}^{2}$ per day, which is equivalent to those rates in B-Pond and U-Pond but higher than that of West Pond (Table 3 ).

The submerged vascular plant, pondweed (Potamogeton), hornwort (Ceratophyllum), and water milfoil (Myriophyllum), grow luxuriantly in Gable Pond (Table 4). Cattails (Typha) and bulrushes ( large stands in the shallower regions (Figure 2). Willows (Salix) and cottonwoods (Populus) are also found at one location of the pond's perimeter. Gable Pond has considerably more of its bottom surface covered with macrophytes ( $>50 \%$ ) than other Hanford ponds (<50\%).

This pond supports a common variety of invertebrate life including flatworms, leeches and segmented worms, crustaceans, snails and numerous families of insects (Table 5). Among these invertebrates the waterflea Daphnia, the scud Hyalella, the predaceous dragonfly Aeschna, and the snail Lymnaea are of notably large abundance. This invertebrate population colonized a bare substrate (lucite) at a mean rate of 1020 organisms $/ \mathrm{m}^{2}$ 
per day, which was the highest among ponds (Table 3). When allowed to colonize $2 \mathrm{~m}^{2}$ of a textile (burlap) substrate for 4 weeks, this population produced an average of 245 individuals, representing 8 families. These data provided a mean community diversity index of 2.1 ( $\mathrm{H}^{\prime}$, Table 3$)$, which was equivalent to that of $U$-Pond and higher than those of the other ponds. The evenness index ( $J^{\prime}$, Table 3 ), which expresses how evenly the individuals were distributred among the families on a 0 to 1.0 basis, indicates that the invertebrates in Gable Pond were moderately well distributed among the families $\left(J^{\prime}=0.6\right)$. This is equivalent to the evenness found in $B$-Pond but higher than that of U-Pond and lower than that of West Pond.

Data for all of these parameters indicate that Gable Pond has a moderately complex taxonomic structure in its invertebrate population and suggests that the associated communities are relatively stable and could withstand at least minor forces of perturbation.

In addition to the invertebrates, Gable Pond also has a goldfish population (Carassius) of undetermined size. Their origin is not known, but we assume that they were placed there by Hanford workers before 1970 .

\section{WEST POND}

West Pond also lies in the small valley south of Gable Mountain in the 200-North Area but at a lower elevation (Figures 1 and 2). At this location ground water has surfaced in response to the large quantities of river water transported into the area. It first appeared in 1957. West Pond has an approximate volume of $31,000 \mathrm{~m}^{3}$ (25 acre-ft), surface area of about $79,000 \mathrm{~m}^{2}$ ( 19 acres), and a mean depth of less than a meter (Table 1). A water budget for West Pond has not been determined, but evaporative loss is an important water outflow route. During its short history, evaporation has concentrated and precipitated soluble salts which are indicated by elevated alkalinity, hardness and conductivity (Table 1). This has left a large alkali salt residue at the pond's perimeter (Figure 2). Because of the rapid percolative rates in Hanford vadose zones (the zone between ground surface and ground water), evaporative loss from other ponds is quite smal1 when compared to percolative losses. U-Pond, for example, loses $<5 \%$ of its inflowing water by evaporation (Emery et a1., 1976). 
Although elevated concentrations of radionuclides have been detected in West Pond, it is not used as a waste handling facility. It is possible that naturally occurring radionuclides in the Columbia River, transported to the waste pond system in the 200-Area plateau, have contributed to the pond's radioactivity through gradual evaporative concentration. At one time in its early history, sludge from latrines was dumped into the depression now flooded by West Pond. This probably explains the elevated concentrations of ammonia nitrogen and phosphorus (Table 1).

In spite of its high conductivity and unusual concentrations of nitrogen, phosphorus, hardness and alkalinity, West Pond has an assortment of algae that roughly resembles that of the other Hanford Ponds (Table 2). This algal population is comprised mainly of periphytic diatoms and blue-green algae. The green algae are least abundant in West Pond, relative to the other Hanford ponds. The variety of algal life in West Pond is relatively broad, containing the rarer forms such as euglenoids, dinoflagellates, and cryptomonads. West Pond's periphyton population does not appear to be as large or as active as those of the other ponds, however. Mean periphyton colonization pressure $\left(17 \mu \mathrm{g} \mathrm{Ch} 1 \underline{\mathrm{a}} / \mathrm{cm}^{2}\right.$ per day, Table 3) was lowest among a11 Hanford Ponds. The macrophyte population appearing in West Pond is also very small and limited to a few stands of cattails and bulrushes (Figure 2 and Table 4 ).

The severe chemical conditions and lack of submerged vegetation in west Pond appear to limit the variety of invertebrates that live there. Only oligochaetes and several families of insects inhabit this pond (Table 5). The oligochaetes thrive in the septic sediments, along with the larvae of the damselfly (Ischnura), caddisfly (Tricoptera), midge (Chironomidae) and shorefly (Ephydridae). Backswimmers (Notonectidae) and water boatmen (Corixidae) are also found in West Pond.

This population of invertebrates has the lowest mean colonization rate among those in Hanford ponds and streams ( 188 organisms $/ \mathrm{m}^{2}$ per day, Table 3). The diversity indices are also the lowest among all ponds (Table 3). An average of only 4 families were represented by a mean of 168 organisms colonizing a $4 \mathrm{~m}^{2}$ textile substrate in 1 month. . These data - produced a mean community diversity index $\left(\mathrm{H}^{\prime}\right)$ of 1.2 and a mean evenness 
index (J') of 0.5. Since data for these parameters are lowest among ponds, they suggest that the complexity of this invertebrate population has been reduced by the unusual chemical conditions and that the associated communities have experienced repression in their normal successional patterns. This also suggests that the community structure and stability is relatively reduced in the West Pond ecosystem.

There are no fish in West Pond.

B-POND, B-3 AND A-29 DITCHES

B-Pond was created in 1945 to receive cooling water from B-Plant in the 200-East Area where waste strontium and cesium were separated from spent fuel elements and encapsulated (Figures 1 and 3 ). It also received cooling water from the Purex Plant. Like Gable Pond, it contains small amounts of actinides and mixed fission products. These nuclides reached $B$-Pond from a rupture in the cooling coils at the Purex Plant in 1964, and also from the B-Plant in 1973 following an accidental spill of strontium bearing wastes.

B-Pond has a surface area of approximately $150,000 \mathrm{~m}^{2}$ (37 acres), a volume of about $233,000 \mathrm{~m}^{3}(190 \mathrm{acre}-\mathrm{ft})$, and a mean depth of $1.6 \mathrm{~m}$ $(5.2 \mathrm{ft}$, Table 1, Figure 3$)$. Its mean hydraulic retention time is $424 \mathrm{hr}$, with an inflow rate of about $10 \mathrm{~m}^{3} / \mathrm{min}(2,600 \mathrm{gal} / \mathrm{min}) \mathrm{via} B-3$ and $\mathrm{A}-29$ ditches (Figure 3 ). As there are no surface outflows from the pond, percolation, mainly, and evaporative loss are the only outflowing routes.

Algae appearing in B-Pond are also predominantly periphytic and similar to those in Gable Pond (Table 2). Families of cyanophytes, chlorophytes, and diatoms are we 11 represented in B-Pond but the euglenoids and dinoflagellates are absent. Cryptomonads appear in B-Pond, as well as in U-Pond and West Pond.

Periphyton grew on a bare substrate at a mean rate of $73 \mu \mathrm{g} \mathrm{Chl} \mathrm{a/ \textrm {cm } ^ { 2 }}$ per day, which is the highest rate among ponds, but similar to those of Gable Pond and U-Pond.

B-Pond is sparsely populated with vascular plants (Table 4). It has a few stands of cattails and bulrushes (Figure 3) and its pondweed population is relatively small. 
The invertebrate population of B-Pond resembles those of Gable Pond and U-Pond (Table 5). Flatworms, segmented worms, crustaceans, insects and snails are all represented. Among these, scuds and water boatmen are particularly abundant. Our sampling also indicates that predaceous dragonfly larvae are not as abundant as in Gable Pond or U-Pond. This is likely due to the lack of submerged vascular plant material that could provide a habitat suitable for these larger insects that require localized concentrations of prey for satisfactory feeding conditions. The invertebrate population colonized a bare substrate at a mean rate of 777 organisms $/ \mathrm{m}^{2}$ per day (Table 3 ). This is less than the colonization rate in Gable Pond but more than those in U-Pond or West Pond.

In sampling for community diversity data, an average of 7 families of invertebrates were represented by a mean of 295 individuals colonizing a textile substrate in 1 month. This produced a mean $H^{\prime}$ of 1.7 which is lower than those for Gable Pond and U-Pond but higher than that of West Pond. The evenness of taxonomic distribution (mean $J^{\prime}=0.6$ ) is equivalent to Gable Pond but lower than U-Pond and higher than west Pond. These diversity expressions suggest that B-Pond has a relatively stable invertebrate population and that the associated communities are moderately flexible to changes that influence aquatic ecosystems.

B-Pond also has a small population of goldfish of undetermined size.

B-3 ditch (Figure 3) carries cooling water to B-Pond from the encapsulation facility. This ditch was modified in 1973 following an accidental spill of strontium bearing wastes. The original ditch was backfilled and the present B-3 ditch has not had a contamination event. B-3 ditch is about $1,200 \mathrm{~m}(4000 \mathrm{ft})$ long, with a maximum depth of $<1 \mathrm{~m}(<3 \mathrm{ft})$ and a mean flow rate of $11 \mathrm{~m}^{3} / \mathrm{min}(6.3 \mathrm{cfs}$, Table 6$)$.

A-29 ditch carried chemical sewer wastes and cooling water from the 200-East Area into B-Pond via the lower third of B-3 ditch (Figure 3). It was formed in 1955 to carry chemical waste water from the Purex Plant. In 1972, a 11 purex laboratory drains were rerouted and A-29 ditch now receives mostly condenser cooling water from an acid fractionator with occasional pulses of waste chemicals. A-29 ditch is approximately $1,300 \mathrm{~m}(4,250 \mathrm{ft})$ 
long, having a maximum depth of $<0.5 \mathrm{~m}(<2 \mathrm{ft})$ and a mean flow rate of $1.5 \mathrm{~m}^{3} / \mathrm{min}(0.9 \mathrm{cfs}$, Table 6$)$.

Both of these streams have chemical conditions that are similar to B-Pond (the receiving body) and Gable Pond, although the ammonia-nitrogen concentrations in Gable Pond are lower (Tables 1 and 6). A-29 ditch, however, is known to occasionally receive wastes containing oils and strong caustics and corrosives.

B-3 and A-29 ditches have relatively diverse algal populations although B-3 ditch appears to be richer in variety than A-29 ditch (Table 2). Both algal populations appear to be periphytic in nature and are composed mainly of cyanophytes, chlorophytes, and diatoms. Neither system appears to have euglenoids or dinoflagellates, but both show appearances of cryptomonads.

The rates of periphyton colonization in these streams are quite different (Table 3 ). B-3 ditch has the highest mean rate of chlorophyll a accumulation on a bare substrate of all Hanford systens sampled ( $87 \mathrm{\mu g} \mathrm{Ch}$ $\underline{a} / \mathrm{cm}^{2}$ per day), while A-29 ditch has the lowest $\left(6 \mu \mathrm{g} \mathrm{Ch} 1\right.$ a $/ \mathrm{cm}^{2}$ per day).

The populations of macrophytes in these streams are limited to cattails, bulrushes and speedwell (Veronica), and several cottonwood trees appear along A-29 ditch (Table 4). The reduced periphyton and macrophyte production in A-29 ditch may be associated with the chemical nature of wastes that enter it intermittently. This ditch frequently receives effluents containing caustics, corrosives, oils, and organic compounds which appear to limit the forms of aquatic life. On several occasions, we observed oil coating the surfaces of our sampling devices.

These occassionally harsh chemical conditions in A-29 ditch also appear to 1 imit the invertebrate population (Table 5). Midge larvae are the only invertebrates that appear in abundance, however, flatworms, oligochaetes, water striders, and black fly larvae were also observed. This invertebrate population shows a relatively low colonization rate $\left(275\right.$ organisms $/ \mathrm{m}^{2}$ per day, Table 3) and attempts to use textile substrates to collect invertebrates for diversity index determinations were unsuccessful. 
B-3 ditch, however, has a relatively varied invertebrate population (Table 5). We have observed representatives of flatworms, oligochaetes, crustaceans, and a variety of insects in this stream. The insect population includes an abundance of midge larvae, along with waterstriders, predaceous diving beetles, and larvae of dragonflies, damselflies, caddisflies, and aquatic caterpillers. Goldfish also appear in B-3 ditch.

This invertebrate population shows the most rapid mean colonization rate among the study sites ( 1610 organisms $/ \mathrm{m}^{2}$ per day, Table 3 ). However, it appears that midge larvae are responsible for most of the colonization pressure. In sampling to determine diversity indices, we found mostly chironomids colonizing the textile substrate, producing a very low mean $H^{\prime}$ of 0.1 (Table 3$)$. The mean evenness index for $B-3$ ditch $\left(J^{\prime}=0.04\right)$ also indicates that the invertebrates appearing on the substrate (mean $N=5964$ ) were disproportionately distributed among the families (mean $s=6$ ).

\section{U-POND AND Z-19 DITCH}

From a radioecological point of view, U-Pond is the most interesting aquatic system at Hanford. It was formed in 1944 in the southwest corner of the 200-West Area (Figure 1 and 4 ). This pond was developed to receive waste water from plutonium processing and reclamation facilities, a laundry, a uranium recovery plant, and several other supportive facilities in the 200-West Area. Plutonium and uranium processing operations have used a series of Z-ditches to receive their effluents. Z-19 ditch is presently serving these laboratories which have reduced their operations in recent years (Figure 4). The laundry, where protective clothing is cleaned, discharges into U-Pond via U-14 ditch. In 1974, U-Pond began receiving cooling water from an evaporator-crystallizer plant via U-14 ditch. This source now constitutes $280 \%$ of U-Pond's water supply (Emery et a1., 1976).

U-Pond has a surface area of approximately $57,000 \mathrm{~m}^{2}$ ( 14 acres), a volume of $22,700 \mathrm{~m}^{3}(18.4 \mathrm{acre}-\mathrm{ft})$, and a mean depth of $0.4 \mathrm{~m}(1.3 \mathrm{ft}$, Table 1). It receives a combined inflow of approximately $10 \mathrm{~m}^{3} / \mathrm{min}$ $(2,600 \mathrm{gal} / \mathrm{min})$ and has a very short hydraulic retention time of about $40 \mathrm{hr}$. Water passes much more rapidly through U-Pond than other ponds at 
Hanford. More than $95 \%$ of the water entering U-Pond leaves via percolation.

U-Pond is unique among aquatic ecosystems. It has uncommonly large quantities of actinides and has contained transuranic elements longer than any other aquatic system. Approximately $5,000 \mathrm{~kg}$ (5.5 tons) of ${ }^{238} \mathrm{U}$ and $20 \mathrm{~g}(0.6 \mathrm{oz})$ of ${ }^{239,240} \mathrm{Pu}$ reside in U-Pond sediments (Emery and Garland, 1974). This pond also contains small quantities of mixed fission and activation products (Figure 4 ). These materials have reached U-Pond via Z-ditches, coming mainly from a few accidental spills in laboratories supporting nuclear reprocessing operations.

U-Pond's algal population is the most diverse among Hanford ponds and streams (Table 2). It contains blue-qreen, green and euglenoid algae, along with diatoms, dinoflagellates, and cryptomonads. Unlike other Hanford ponds, U-Pond does not support a predominantly periphytic algal population. The most abundant algal forms are the filamentous green alga Cladophora and the colonial green alga Tetrospora. Both of these algae grow in floating or submerged masses and develop large standing crops during the summer months $(\sim 13,000 \mathrm{~kg}$ of biomass per year, Emery et a1., 1978).

U-Pond also supports the broadest assortment of vascular plants among Hanford aquatic systems (Table 4). Of particularly large abundance are pondweeds and cattails. Cottonwood and willow grow along more than half of the pond's perimeter and on a small island near its center (Figure 4). Also present are horsetails (Equisetum), duckweek (Lemna), bulrushes (Scirpus), smartweed (Polygonum), watercress (Rorippa) and wild lettuce (Lactuca).

U-Pond has elevated concentrations of phosphate which is an essential plant nutrient (Table 1). The sources of this enrichment are effluents from a laundry carried by U-14 ditch (Figure 4) and to a lesser extent, Z-19 ditch which also carried high phosphate concentrations into U-Pond (Table 6). To determine the photosynthetic activity of plant life responding to this enrichment, rates of carbon uptake were analyzed on a pondwide basis (Table 3). U-Pond's primary productivity occurred as high as $42 \mathrm{~kg}$ of $\mathrm{C} /$ hectare per day, which reflects its eutrophic state. This rate of productivity may also be expressed as $440 \mu \mathrm{g} \mathrm{C} / \ell$ per hour. Using an 
identical method, Verduin (1964) found primary productivity rates in two Pennsylvania ponds to range from 120 to $760 \mu \mathrm{g} \mathrm{C} / \mathrm{l}$ per $\mathrm{hr}$. Hence, U-Pond's primary productivity resemb les that in some ponds not associated with nuclear facilities. Its rate of carbon assimilation also approaches that of a highly productive terrestrial community, a corn field, which has an average assimilation rate of $63 \mathrm{~kg}$ of C/hectare per day (Robbins et al., 1957).

Many of the plant forms that contribute to the overall primary productivity in U-Pond are submerged macrophytes that are rooted in the sediments. However, the photosynthetic activity of these vascular plants appears to be unaffected by the $5000 \mathrm{~kg}$ of ${ }^{238} \mathrm{U}$ that have been deposited in the sediments in concentrations averaging $647 \mu \mathrm{g} / \mathrm{g}$ or $0.6 \%$ (Emery and Garland, 1974).

The mean rate with which periphyton colonize a bare substrate in U-Pond (54 $\mu \mathrm{g} \mathrm{Ch} 1 \underline{a} / \mathrm{cm}^{2}$ per day, Table 3 ) is similar to the production rates of Gable Pond and B-Pond and higher than that of West Pond.

This relatively high abundance of vascular plants and algae provide an excellent habitat for invertebrate life in U-Pond. Waterflea (Daphnia), damselfly larvae, backswimmers, water boatman, snails, and predaceous dragonfly larvae (Aeschna and Libellula) are relatively abundant (Table 5). Most of the other invertebrate forms found in other Hanford ponds also appear in U-Pond. However, the mean colonization rate for invertebrates on a bare substrate (417 organisms $/ \mathrm{m}^{2}$ per day, Table 3 ) exceeds on ly that of West Pond and is lower than those of Gable Pond (Table 3). The mean community diversity index is the same as that for Gable Pond $\left(H^{\prime}=2.1\right)$, although the mean evenness is higher $\left(\mathrm{J}^{\prime}=0.8\right)$. These diversity data suggest that U-Pond's community structure is the most stable of Hanford system.

A relatively large population of goldfish lives in U-Pond. These goldfish show a maximum production rate of about $40 \mathrm{~kg} /$ hectare per year (Table 3), with a standing crop of about 75,000 individuals. Estimates of goldfish production in U-Pond are not unusual and fall within the production ranges for suckers and carp reported by Carlander (1955) for a number of North American lakes and reservoirs. 
A series of Z-ditches have carried most of the radioactive effluents into U-Pond over a distance of $885 \mathrm{~m}$ (2,900 ft, Table 2). Effluents discharged from nuclear facility laboratories into these ditches ordinarily contain only low-level activity $(<10 \mathrm{n} \mathrm{Ci} / \mathrm{l})$. 0ccasional releases of effluents containing higher activity were necessitated by infrequent departures from routine operations in the laboratories. In the past, effluents having higher activity that were released into a $Z$-ditch required that it be backfilled and a new one relocated. This practice has prevented much of these materials from reaching U-Pond. Z-19 ditch, formed in 1971, is the most recent of these ditches. However, in March 1976, its supply of water was substantially reduced because of a variation in operations in a connecting laboratory. Prior to this reduction of discharges, Z-19 ditch had a maximum depth of $<0.5 \mathrm{~m}(<2 \mathrm{ft})$ and carried an average flow rate of $0.6 \mathrm{~m}^{3} / \mathrm{min}(0.4 \mathrm{cfs}$, Table 6$)$. At present, its flow rate into U-Pond is $<0.01 \mathrm{~m}^{3} / \mathrm{min}$ and plays a negligible role in the pond's water budget. The elevation of U-Pond is, presently being maintained with cooling water from the evaporatory-crystallizer plant and from laundry effluents carried by U-14 ditch.

The relatively high mean seston concentration of $13.25 \mathrm{mg} / \ell$ (Table 6) indicates that Z-19 ditch carried more suspended particulates than other Hanford streams that were analyzed for this parameter. Its ranges of temperature, $\mathrm{pH}$, alkalinity, and dissolved oxygen resembled those of A-29 and B-3 ditches, but concentrations of plant nutrients were different. The mean concentration of ammonia-nitrogen was lower and mean phosphate and silicate concentrations were higher than those in the other streams that were sampled (Table 6).

The types of algae living in Z-19 ditch were generally similar to those of other Hanford streams, although the variety does not appear to be as large as in A-29 or B-3 ditches (Table 2). Its periphytic algal population represents only four families of diatoms, six families of green and two families of blue-green algae. The predominant algal form in Z-19 ditch was the filamentous green alga Spirogyra, growing attached to vascular plant material. Cryptomonads, dinoflagellates and euglenoid algae were not 
detected in Z-19 ditch. Since this stream contains relatively higher levels of radioactivity, it would have been desirable to measure its periphyton colonization pressure. However, this analysis could not be performed without contaminating expensive equipment that was needed for other studies.

Despite its relatively small variety of algae, Z-19 ditch has a fairly broad assortments of vascular plants (Table 4). It is richly populated with pondweed and cattails, and also supports bulrushes, speedwe 11, watercress, and wild lettuce. Cottonwoods also grow along the banks of this stream.

Only seven invertebrate forms were detected in Z-19 ditch (Table 5). These are 0 ligochaetes and insects including waterstriders, backswimmers, waterboatmen, and the larvae of midges and damselflies. Mean colonization rates of these invertebrates could not be determined due to inadequate yields from the lucite sampling substrates, although we estimate that they do not colonize more rapidly than 100 organisms $/ \mathrm{m}^{2}$ per day (Table 3 ). Even the burlap substrates used for determining diversity indices attracted invertebrates at a mean rate of on ly 6 individuals per month, representing just 2 families. The resulting diversity indices were lower than indices in 100-N trench and the ponds, but generally higher than those in B-3 and A-29 ditches (Table 3 ). These low mean indices for community diversity $\left(H^{\prime}=0.3\right)$ and evenness $\left(J^{\prime}=0.3\right)$, in addition to the limited variety of algal forms, suggest than Z-19 ditch has not attained successional stability in spite of plentiful substrates provided by a variety of macrophytes.

\section{0-N TRENCH}

The remaining study site, $100-\mathrm{N}$ trench, stands apart from the rest in several ways. Radionuclide concentrations and dose rates in $100-\mathrm{N}$ trench are considerably higher than those of other study sites, although Z-19 ditch has higher $\alpha$ concentrations. It has received cooling water directly from the 1301-N crib at the $N$-reactor site since 1962-63 (Figures 1 and 5 ). This crib is used to store radioactive wastes that are routine by-products of nuclear processes within the reactor. The combination of mixed fission and activation products and actinides including transuranic elements that are 
present in this water have entered through small leaks in the cooling manifold. Occasionally, 100-N trench receives contaminates from $\mathrm{N}$-reactor following a fuel element failure.

In addition to these characteristics, this trench is less than half the length but more than twice the width of the other Hanford study ditches (Table 6 ). It accommodates a flow rate of approximately $7 \mathrm{~m}^{3} / \mathrm{min}$ ( $4 \mathrm{cfs}$ ) over a surface area of about $2440 \mathrm{~m}^{2}\left(26,300 \mathrm{ft}^{2}\right)$. This creates a slow moving lotic (running water) environment with a maximum depth of $<1 \mathrm{~m}$ $(<3 \mathrm{ft})$. Final1y, the close proximity of 100-N trench to 1301-N crib of ten causes waste heat to enter this aquatic environment. Temperatures in 100-N trench are frequently 8-10 C higher than in other aquatic sites (Table 6).

The variety of algal forms occurring in 100-N trench is similar to that in Z-19 ditch. The diatoms (four families), blue-green algae (two families) and some of the green algae (five families) occurring in 100-N trench are periphytic, but unattached masses of Spirogyra and Hydrodictyon are also abundant (Table 2). Levels of radioactivity in this trench prevented $\mathrm{Ch} 1 \underline{\mathrm{a}}$ analyses that were needed for periphyton colonization pressure determinations.

Vascular plants appearing in 100-N trench are limited to a few stands of butrush and speedwel1 (Table 4). This may be caused by a limited physical habitat since $100-\mathrm{N}$ trench is deep ly recessed between $3.6 \mathrm{~m}$ (12 ft) high embankments and is covered with an iron screen (10 cm or $6 \mathrm{in}$. mesh) to reduce contract with wildlife. The collective effect of the height and steep slope of the embankments $\left(\sim 30^{\circ}\right)$ and tumbleweed captured by the screen reduces light penetration to areas of the trench that might otherwise support macrophyte populations. This trench is also heated more frequently and to higher temperatures than the other systems (Table 6) which could suppress the growth of macrophytes.

Invertebrate life in $100-\mathrm{N}$ trench is relatively limited in variety (Table 5). There is an abundance of snails (Lymnaea) and midge Tarvae along with appearances of dragonfly and damselfly larvae, backswimmers, and oligochaetes. The colonization pressure of this invertebrate population is higher than the other aquatic systems except Gable Pond and B-3 ditch (mean 
colonization rate $=897$ organisms $/ \mathrm{m}^{2}$ per day, Table 3 ). Many of these organisms are midge larvae, however, which is reflected by a lower mean community diversity index, relative to ponds, and a moderately low mean evenness index $\left(H^{\prime}=0.9\right.$ and $J^{\prime}=0.5$, Table 3$)$.

In general, the variety of aquatic life appearing in $100-\mathrm{N}$ trench seems reduced in contrast to most of the other study systems, although the activity of these biota in terms of observable algal growths and invertebrate colonization pressure appears comparable to those of several Hanford ponds. 


\section{DISTRIBUTION}

No. of

Copies

\section{OFFSITE}

A. A. Churm

U.S. DOE Chicage Patent Attorney 9800 South Cass Avenue

Argonne, IL 60439

J. Swinebroad

U.S. DOE Office of Health and Environmental Research

washington, DC 20545

R. L. Watters

U.S. DOE Office of Health and Environmental Research Washington, DC 20545

T. C. Chee

U.S. DOE Office of Nuclear Waste Management

Washington, DC 20545

27 U.S. DOE Technical Information Center

0. D. Markham

Environmental Sciences Branch

Health Services Laboratory

U.S. DOE

P.0. Box 2108

Idaho Falls, ID 83410

M. Smith, Director

Savannah River Ecology Laboratory Drawer E

Aiken, SC 29801

L. D. Eyman

Environmental Sciences Division

Oak Ridge National Laboratory

P.0. Box X

Oak Ridge, Tennessee 37830
No. of

Copies
F. W. Whicker

Radiology and Radiation

Biology Department

Colorado State University

Fort Collins, CO 80521

T. E. Hakonson

Los Alamos Scientific Laboratory

P.0. Box 1663

Los Alamos, NM 87544

E. B. Fowler

$\mathrm{H}-7, \mathrm{MS}-578$

Los Alamos Scientific Laboratory

P.0. Box 1663

Los Alamos, NM 87544

ONSITE

4 U.S. DOE - U.S. DEPARTMENT

OF ENERGY $-R L$

H. E. Ransom (2)

J. L. Rhodes

M. W. Tiernan/P. F. X. Dunigan

8 Rockwel1 Hanford Operations

D. J. Brown

L. E. Burns

R. A. Deju

R. D. Fox

R. E. Isaacson

D. Paine

J. V. Panesko

2 United Nuclear Inc.

T. E. Dabrowsk i

L. P. Diediker 
76 Pacific Northwest Laboratories

W. J. Blair

B. W. Compton (4)

C. E. Cushing

L. L. Eberhardt

R. M. Emery (52)

R. F. Foster

M. C. McShane

W. H. Rickard

L. E. Rogers

R. G. Schreckhise

J. A. Strand

W. L. Templeton

B. E. Vaughan

D. G. Watson

Technical Information (5)

Publishing Coordination (2) 